\title{
INTERNATIONAL HUMAN RIGHTS LAW AND \\ NATURAL RESOURCES ProJects Within THE TrAditional TERRITORIES OF INDIGENOUS PEOPLES
}

\author{
NIGEL BANKES*
}

This article explores the relevance of international human rights law to natural resource developments within the traditional territories of indigenous peoples. The author argues that international law prescribes standards that limit the authority of the state to grant resource rights to third parties and to approve resource projects within the traditional territories of indigenous peoples. In making this argument, the article examines interactions between recent developments in human rights law and the domestic legal system. The author approaches the topic through an examination of how several recent international decisions deal with conflict between territorial rights asserted by indigenous peoples and resource development permits granted by domestic governments within those territories. The article suggests that these decisions point to an emerging trend on the international human rights stage to interpret international rights instruments as requiring consideration of the relationship of indigenous peoples to the land prior to allowing resource exploitation.
Cet article porte sur la pertinence du droit international en matière de droits de la personne dans le cas d'exploitations de ressources naturelles sur les territoires traditionnels des peuples autochtones. L'auteur fait valoir que le droit international établit les normes limitant l'autorité de l'État à accorder des droits de ressources à des tiers et d'approuver de tels projets sur les territoires traditionnels des peuples autochtones. En invoquant cet argument, l'auteur examine les interactions entre les récents développements des droits de la personne et le système juridique en vigueur au pays. L'auteur aborde le sujet en étudiant la manière dont plusieurs récentes décisions internationales ont traité les conflits entre les droits territoriaux revendiqués par les peuples autochtones et les permis d'exploitation accordés par les gouvernements nationaux pour ces territoires. L'article laisse entendre que ces décisions attirent l'attention sur une tendance émergente des droits internationaux de la personne de manière à interpréter les instruments de droits internationaux à devoir tenir compte de la relation des peuples autochtones vivant sur ces terres avant de permettre la mise en valeur des ressources.

\section{TABLE OF CONTENTS}

I. INTRODUCTION . . . . . . . . . . . . . . . . . . . . . . . . 458

A. Some General Propositions as to the Sources

OF INTERNATIONAL LAW AND THE EFFECT OF

INTERNATIONAL LAW WITHIN THE DOMESTIC LEGAL SYSTEM . . . . 462

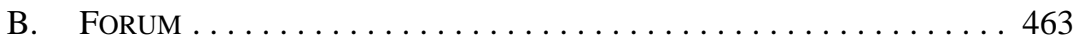

II. The International Covenant on Civil and Political Rights . . . . . 465

A. ARTICLE 27 OF THE INTERNATIONAL COVENANT ON CIVIL AND POLITICAL RIGHTS . . . . . . . . . . . . . . . . . . . 465

B. THE HUMAN RightS COMMITTEE'S

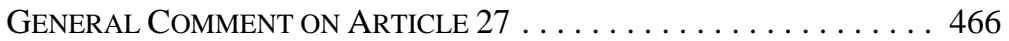

C. Human Rights Committee Decisions

ON ARTICLE 27: THE JURISPRUDENCE . . . . . . . . . . . . . . . . . . 467

D. THE LÄNSMAN DECISIONS . . . . . . . . . . . . . . . . . 469

E. Conclusions With Respect to ARticle $27 \ldots \ldots \ldots \ldots$. . . . 473

F. ARTiCle 1(2) OF THE CovenANTS AND the DoCTRine OF PERMANENT SOVEREIGNTy Over NATURAL Resources . . . . 476 
III. THE INTER-AMERICAN HumAn RightS SySTEM . . . . . . . . . . . . . 478

A. THE JURISPRUDENCE OF THE INTER-AMERICAN

COURT OF HUMAN Rights ... . . . . . . . . . . . . . . . . . . . . . 479

B. The Right to Judicial Protection . . . . . . . . . . . . . . 480

C. The Right to Property $\ldots \ldots \ldots \ldots \ldots \ldots \ldots \ldots \ldots \ldots \ldots 42$

D. The Content of the Protected Interest $\ldots \ldots \ldots \ldots$. . . . . . . 487

E. The Power of the Saramaka State . . . . . . . . . . . 488

F. CONCLUSIONS WITH RESPECT TO THE

JURISPRUDENCE OF THE COURT . . . . . . . . . . . . . . . . . . . . . 491

G. THE JURISPRUDENCE OF THE COMMISSION ON THE

AMERICAN DECLARATION ON THE RIGHTS AND DUTIES OF MAN . . . . 491

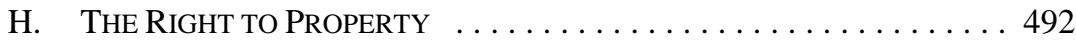

I. The Right to EQUALITY Before the LAW . . . . . . . . . . . . . . . 492

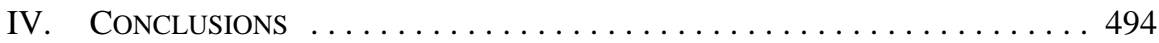

\section{INTRODUCTION}

Over the last two decades and more we have seen significant development in the field of law known in Canada as aboriginal law. Much of that development has been a response to the constitutional entrenchment of "[t]he existing aboriginal and treaty rights of the aboriginal peoples of Canada." ${ }^{1}$ But we have also seen developments in fiduciary law ${ }^{2}$ and in the law pertaining to the interpretation of treaties. ${ }^{3}$ In addition, the courts have developed a body of law on the Crown's duty to consult and accommodate aboriginal peoples, which is perhaps best described as part of our constitutional common law. ${ }^{4}$ Other common law countries such as Australia and New Zealand have seen similar developments in the law pertaining to the relationship between indigenous peoples and the settler state. These developments are not confined to common law countries. There have also been significant developments in other jurisdictions, notably in Scandinavia and, most particularly, in Norway. ${ }^{5}$

Constitution Act, 1982, s. 35, being Schedule B to the Canada Act 1982 (U.K.), 1982, c. 11; R. v. Sparrow, [1990] 1 S.C.R. 1075.

2 Guerin v. The Queen, [1984] 2 S.C.R. 335; Blueberry River Indian Band v. Canada (Department of Indian Affairs and Northern Development), [1995] 4 S.C.R. 344; Wewakum Indian Band v. Canada, 2002 SCC 79, [2002] 4 S.C.R. 425.

Simon v. The Queen, [1985] 2 S.C.R. 387; R. v. Sioui, [1990] 1 S.C.R. 1025 [Sioui]; R. v. Badger, [1996] 1 S.C.R. 771 [Badger]; R. v. Marshall, [1999] 3 S.C.R. 456; Mikisew Cree First Nation v. Canada (Minister of Canadian Heritage), 2005 SCC 69, [2005] 3 S.C.R. 388 [Mikisew Cree].

$4 \quad$ Haida Nation v. British Columbia (Minister of Forests), 2004 SCC 73, [2004] 3 S.C.R. 511; Taku River Tlingit First Nation v. British Columbia (Project Assessment Director), 2004 SCC 74, [2004] 3 S.C.R. 550; for some of the literature see Sonia Lawrence \& Patrick Macklem, "From Consultation to Reconciliation: Aboriginal Rights and the Crown’s Duty to Consult” (2000) 79 Can. Bar Rev. 252; Thomas Isaac \& Anthony Knox, “The Crown’s Duty to Consult Aboriginal People” (2003) 41 Alta. L. Rev. 49; Richard F. Devlin \& Ronalda Murphy, "Contextualizing the Duty to Consult: Clarification or Transformation?” (2003) 14 N.J.C.L. 167; Tony Fogarassy \& KayLynn Litton, "Consultation with Aboriginal Peoples: Impacts on the Petroleum Industry” (2004) 42 Alta. L. Rev. 41; Kirk Lambrecht, "Environmental Assessment and Aboriginal Consultation: One Sovereignty or Two Solitudes" in Stanley Berger \& Dianne Saxe, eds., Environmental Law: The Year in Review 2007 (Aurora: Canada Law Book, 2008) 73; Verónica Potes, Monique Passelac-Ross \& Nigel Bankes, Oil and Gas Development and the Crown's Duty to Consult: A Critical Analysis of Alberta's Consultation Policy and Practice, Research Report Paper No. 14 of the Alberta Energy Futures Project, 2006, online: Institute for Sustainable Energy, Environment and Economy < http://www.iseee.ca/files/iseee/ABEnergy Futures14.pdf $>$.

$5 \quad$ For a survey see Nigel Bankes, "Legal Systems” in Níels Einarsson et al., eds., AHDR Arctic Human Development Report (Akureyri: Stefansson Arctic Institute, 2004) 101. 
In some cases the principal drivers for change seem to be internal to the domestic legal system. This is most obviously the case in Canada. But in other cases, international law, specifically international human rights law, has played an important role. This is certainly the case in Norway, ${ }^{6}$ but even in Australia the High Court decisions in Mabo \# $1^{7}$ and Mabo $\# 2^{8}$ drew on international human rights law in important ways to support the abolition of the doctrine of terra nullius in Australian law.

International law itself has also been developing apace over this same period. Key developments include the adoption of the International Labour Organization's (ILO) Convention (No. 169) Concerning Indigenous and Tribal Peoples in Independent Countries ${ }^{9}$ and the adoption of the United Nations Declaration on the Rights of Indigenous Peoples. ${ }^{10}$ Efforts to draft a similar declaration within the Inter-American system, ${ }^{11}$ and the efforts of the Scandinavian countries to draft a Nordic Sami Convention, have also played key parts in this process. ${ }^{12}$ The developments have not been confined to treaty making and declaration drafting. Judicial bodies such as the Inter-American Court of Human Rights have been actively engaged in developing the relevant law, as have various international human rights monitoring bodies such as the United Nations Human Rights Committee, which is responsible for the International Covenant on Civil and Political Rights, ${ }^{13}$ and the Committee on the Elimination of Racial Discrimination, which is responsible for the International Convention on the Elimination of All Forms of Racial Discrimination. ${ }^{14}$

The interaction between these developments in international law and the domestic legal system is the subject of this article. Thus far, these developments in international law have not had much influence within the domestic law or politics of Canada and less influence here than in most, if not all, of the other jurisdictions mentioned above. This seems to hold true for both the judicial and the executive branches, as well as within quasi-judicial boards such as the Energy Resources Conservation Board. Not only have Canadian courts rarely referred to international human rights law in the context of aboriginal rights cases, but the executive branch of government has refused to endorse the United Nations Declaration on the Rights

See in particular Hans Petter Graver \& Geir Ulfstein, “The Sami People’s Right to Land in Norway” (2004) 11 International Journal on Minority and Group Rights 337. This is a translation of the opinion provided by these two scholars at the request of the Stortinget (the Norwegian parliament).

Mabo v. Queensland (No. 1), [1988] HCA 69, 166 C.L.R. 186 [Mabo \# 1].

Mabo v. Queensland (No. 2), [1992] HCA 23, 175 C.L.R. 1 [Mabo \# 2].

27 June 1989, 1650 U.N.T.S. 383 (entered into force 5 September 1991) [ILO Convention 169] and for commentary see Luis Rodrígues-Piñero, Indigenous Peoples, Postcolonialism, and International Law: The ILO Regime (1919-1989) (Oxford: Oxford University Press, 2005).

$10 \quad$ GA Res. 61/295, UN GAOR, 61st Sess., Supp. No. 49, UN Doc. A/61/49 (2008) 15.

11 For the web page of the Working Group to Prepare the Draft American Declaration on the Rights of Indigenous Peoples see online: Organization of American States (OAS) <http://www.oas.org/consejo/ CAJP/Indigenous\%20special\%20session.asp>.

12 The Nordic Council commenced a procedure to develop a Nordic Sami Convention with the active involvement of the three Sami parliaments. An expert committee has produced a draft convention and it is now up to the three states to decide whether to commence negotiations based on the draft. For discussion of the draft and the process that led to it see Timo Koivurova, "The Draft Nordic Saami Convention: Nations Working Together” (2008) 10 International Community Law Review 279. An English translation of the draft text is available online: Saami Council <http://www.saamicouncil. net ? newsid=2223\&deptid=2192\&languageid=4\&news $=1>$. 
of Indigenous Peoples ${ }^{15}$ and, for a number of reasons, there has been little interest in ratifying the ILO Convention 169. ${ }^{16}$

I think that this lack of influence of (and perhaps lack of interest in and respect for) international human rights law will change for several reasons. First, the practice in Canada is out of step with practice in other states. ${ }^{17}$ Second, sooner or later we will have to "bring home"18 the learning from international judicial and monitoring bodies, particularly those within the Inter-American system now that Canada is a member of the Organization of American States (OAS), if we are to maintain our international standing as a state that respects human rights and the rule of law. Finally, investors such as Norway's StatoilHydro may themselves question (or be required to do so by their shareholders or others) whether their own actions, such as oil sands activities, are consistent with and respectful of the human rights of indigenous peoples and the investors' corporate social responsibility commitments. ${ }^{19}$

This article explores the relevance of international human rights law to natural resource developments within the traditional territories of indigenous peoples. The main argument is that international law prescribes standards that limit the authority of the state to grant resource rights to third parties and to approve resource projects within the traditional territories of indigenous peoples. These standards apply in addition to any that apply as a matter of domestic law by way of treaty, agreement between the state and indigenous people, or otherwise. I have not provided here an account of the economic, cultural, and spiritual importance of land and territory to indigenous peoples. I simply take that as a given. ${ }^{20}$ Nor do I see the need to lengthen this article with a long account of the potential for conflict between the extractive industries and indigenous peoples' use of territory. I will also take that as a given ${ }^{21}$ understanding in each case that both of these assumptions may be contested and become the subject of evidence in a concrete situation. ${ }^{22}$

In order to keep the article within a manageable size I have canvassed a fairly narrow range of sources, specifically art. 27 of the ICCPR, with some shorter comments on art. 1, and the equality rights, property rights, and effective protection rights found in the American

John McNee, "Statement by Ambassador John McNee Permanent Representative of Canada to the United Nations to the 61st Session of the General Assembly on the Declaration on the Rights of Indigenous Peoples” (New York, 13 September 2007), online: Indian and Northern Affairs Canada $<$ http://www.ainc-inac.gc.ca/ap/ia/stmt/2007/undir-eng.asp>. Although the current federal conservative government remains opposed to endorsing the Declaration, they formed a minority government and on 8 April 2008 the House of Commons adopted a resolution calling on them to endorse the Declaration. I discuss some of the reasons for this in Nigel Bankes, "Land Claim Agreements in Arctic Canada in Light of International Human Rights Norms" (2009) 1 Yearbook of Polar Law 175 [Bankes, "Land Claim Agreements"].

17 By practice I simply mean the practice of lawyers and judges in referring to and using arguments based on international law.

18 Harold Hongju Koh, “The 1998 Frankel Lecture: Bringing International Law Home” (1998) 35 Hous. L. Rev. 623.

19 Canadian companies are certainly aware of these issues when operating overseas: see e.g. Jonathan Horlick et al., "American and Canadian Civil Actions Alleging Human Rights Violations Abroad by Oil and Gas Companies” (2008) 45 Alta. L. Rev. 653.

$20 \quad$ For a particularly compelling judicial statement of this see the joint separate concurring opinion of Judges Cançado Trindade, Pacheco Gómez \& Abreu-Burelli in the Case of the Mayagna (Sumo) Awas Tingni Community v. Nicaragua (2001), Inter-Am. Ct. H.R. (Ser. C) No. 79 [Awas Tingni].

21 See generally Forest Peoples Programmes, Extracting Promises: Indigenous Peoples, Extractive Industries and the World Bank: Final (Synthesis Report, May 2003) by Emily Caruso et al., online: Bankwatch <http://bankwatch.ecn.cz/eir/reports/vol6_3.pdf>. See e.g. the discussion of the Lubicon case, below. 
Convention on Human Rights ${ }^{23}$ and the American Declaration on the Rights and Duties of Man. ${ }^{24}$ I have chosen to focus on these instruments because they have produced a body of jurisprudence that should be more familiar and accessible to the non-international lawyer than some of the "softer" instruments with which international lawyers typically deal. Thus, the article is not exhaustive. It does not analyze or draw upon the ILO Convention 169 (principally because Canada is not a party); neither does it scrutinize the lands and resources provisions of the United Nations Declaration on the Rights of Indigenous Peoples (principally because the status of those provisions as declaratory of international law is contested). ${ }^{25} \mathrm{I}$ am also not going to pursue other relevant human rights norms such as are set out in the CERD ${ }^{26}$ the Convention on the Prevention and Punishment of the Crime of Genocide ${ }^{27}$ and softer instruments, such as the World Bank's safeguard policies with respect to bank-funded projects in the traditional territories of indigenous peoples. ${ }^{28} \mathrm{~A}$ complete analysis of the issues raised in this article would need to review all of those sources and more. $^{29}$

The first sections of this article offer general propositions on two preliminary matters: (1) the status of international law within the domestic legal system of Canada and (2) questions of forum, meaning questions concerning where parties can raise the types of issues discussed

2322 November 1969, 1144 U.N.T.S. 143 [American Convention].

24 OAS, Ninth International Conference of American States, American Declaration on the Rights and Duties of Man, OR OEA/Ser.L./V/II.82/Doc.6, rev. 1 (1992) at 17 [American Declaration]. Canada is a party to the two Covenants and to the CERD and is bound by the American Declaration (see discussion below), but Canada is not a party to the American Convention. The rationale for considering the Convention in some detail here rather than other instruments such as the ILO Convention 169 is simply that it is part of the Inter-American system, at least part of which binds Canada, and the institutions of the OAS, the Commission, and the Court take a unified interpretive approach.

25 For Canada's position see the filed submission in the North American Free Trade Agreement Arbitration, Grand River Enterprises Six Nations Ltd. v. United States of America, Government of Canada, Submission pursuant to NAFTA Article 1128, filed 19 January 2009, arguing that both the ILO Convention 169 and the United Nations Declaration on the Rights of Indigenous Peoples lack the generality of state practice and opinio juris to be considered customary international law. The submission is available online: The U.S. Department of State <http://www.state.gov/documents/ organization/115489.pdf>. By contrast in Aurelio Cal v. Belize (AG), Judgment of 18 October 2007, Claim Nos. 171 and 172 of 2007, online: The University of Arizona <http://www.law.arizona. edu/Depts/iplp/advocacy/maya_belize/documents/ClaimNos171and172of2007.pdf $>$ [Aurelio Cal], the Supreme Court of Belize, while recognizing that the Declaration was not binding did suggest that art. 26 dealing with rights to land reflects "the growing consensus and the general principles of international law on indigenous peoples and their lands and resources” (at para. 131). For discussions of the Declaration see Henry Minde, Asbjørn Eide \& Mattias Åhrén, “The UN Declaration on the Rights of Indigenous Peoples - What made it possible? The work and process beyond the final adoption” (2007) 4 Gáldu Č́la Journal of Indigenous Peoples Rights, online: Gáldu <http://www.galdu.org/govat/doc/ galdu_4_07_eng_web.pdf $>$. This special issue contains three essays; the first by Henry Minde, "The destination and the journey Indigenous peoples and the United Nations from the 1960s through 1985," ibid. at 9, the second by Asbjørn Eide, "Rights of indigenous peoples - achievements in international law during the last quarter of a century," ibid. at 40, and the third by Mattias Åhrén, "The UN Declaration on the Rights of Indigenous Peoples - How was it adopted and why is it significant?,” ibid. at 84 . CERD, supra note 14 .

9 December 1948, 78 U.N.T.S. 277 (entered into force 12 January 1951).

See e.g. The World Bank, “Operational Policy 4.10 - Indigenous Peoples,” adopted July 2005, online: The World Bank <http://web.worldbank.org/WBSITE/EXTERNAL/PROJECTS/EXTPOLICIES/ EXTOPMANUAL/0,,contentMDK:20553653 menuPK:4564185 pagePK:64709096 piPK:647091 08 theSitePK:502184,00.html>.

29 Two of the standard texts are S. James Anaya, Indigenous Peoples in International Law, 2d ed. (Oxford: Oxford University Press, 2004) and Patrick Thornberry, Indigenous peoples and human rights (Manchester: Manchester University Press, 2002). See also Anthony Anghie, Imperialism, Sovereignty and the Making of International Law (Cambridge: Cambridge University Press, 2005). 
in this article. ${ }^{30}$ The article then examines art. 27 of the ICCPR as interpreted by the UN Human Rights Committee with some references also to art. 1. The article then turns to examine the relevant provisions of the American Declaration and the American Convention as interpreted respectively by the Inter-American Commission on Human Rights and Court.

\section{A. Some General Propositions as to the Sources of INTERNATIONAL LAW AND THE EFFECT OF INTERNATIONAL LAW WITHIN THE DOMESTIC LEGAL SYSTEM}

Customary international law is part of the common law of Canada and may be applied by a court (absent an irreconcilable conflict with a valid statute) without the need for any further referential incorporation by statute. ${ }^{31}$ Customary law may be applied as a substantive rule in appropriate cases and may also be used to influence the interpretation of statutory powers. ${ }^{32}$ Since customary law is part of the common law of Canada, it need not be presented to a tribunal or court as a matter of evidence but may be argued as a question of law. ${ }^{33}$ A party may lead opinion evidence to demonstrate that a particular proposition does in fact represent customary international law. ${ }^{34}$

A treaty does not change the domestic law or the rights and obligations of citizens, except to the extent that it has been incorporated by a valid (according to the division of powers) statute. There is no specific federal or provincial implementing legislation for the two covenants, the $C E R D$, or the American Declaration. The requirement of incorporation is, however, subject to a number of qualifications based on the following additional propositions. $^{35}$

A treaty may (1) create new law as between the parties, but it may also (2) codify existing customary law, or (3) over time, come to represent custom. To the extent that a treaty falls into the second or third category, further incorporation into domestic law is unnecessary since the norms encoded in the treaty also represent custom. ${ }^{36}$

This is not a article on the relationship between international law and domestic law generally, but I offer some general propositions on these topics in order to help ground the material that follows. For more in-depth discussion of these issues consult John Currie, Public International Law, 2d ed. (Toronto: Irwin Law, 2008) c. 7; Gibran Van Ert, “Using Treaties in Canadian Courts” (2000) 38 Can. Y.B. Int'l Law 3; Jutta Brunée \& Stephen Toope, “A Hesitant Embrace: The Application of International Law by Canadian Courts” (2002) 40 Can. Y.B. Int'l Law 3.

31 Currie, ibid. at 226-35 (although he states the rule somewhat more cautiously); Bouzari v. Islamic Republic of Iran (2004), 71 O.R. (3d) 675 at para. 64 (C.A.) [Bouzari].

32114497 Canada Ltée (Spraytech, Société d'arrosage) v. Hudson (Town of), 2001 SCC 40, [2001] 2 S.C.R. 791 at paras. 30-32 (using the precautionary principle (arguably part of customary law) to provide context to support a particular interpretation of a municipal government statute); Bouzari, ibid. at para. 65.

33 Reference re Secession of Quebec, [1998] 2 S.C.R. 217.

Ibid.

For an argument (based on ideas of parliamentary sovereignty and the democratic principle) from the United Kingdom that the courts should not qualify the breadth of this general proposition see Philip Sales \& Joanne Clement, “International Law in Domestic Courts: the Developing Framework” (2008) 124 Law Q. Rev. 388. In general, this article argues that adoption of the above principles should favour a very cautious approach to the treatment of international law as part of domestic law.

36 This was the argument in Montana Band of Indians v. Canada, [1991] 2 F.C. 30 (C.A.), in which the plaintiffs sought a declaration that arts. 1 and 27 of the ICCPR were binding on Canada and applied to the plaintiffs. In support of that the plaintiffs argued that the Covenant was binding upon Canada as both a treaty that it had ratified and as part of customary international law. 
A treaty that has not been incorporated into domestic law must nevertheless be taken into account in the exercise of statutory discretions and powers. ${ }^{37}$

In interpreting a statute, Parliament is presumed to legislate consistently with its international obligations, and thus, "so far as possible, courts should interpret domestic legislation consistently with these treaty obligations." 38

While Canadian courts have taken the view that a historical treaty between a First Nation and the Crown is not an international treaty, ${ }^{39}$ I think that it is at least arguable that one may use international law as an aid to interpret ambiguous or open-textured language in such a treaty. ${ }^{40}$

\section{B. FORUM}

In what fora may parties raise questions of international law? The above propositions demonstrate the circumstances under which a party may be able to bring an international law matter before a domestic tribunal. The term "domestic tribunal” as used here includes any court of inherent jurisdiction or any statutory court or tribunal or statutory decision-maker with the express or necessary implied authority to decide questions of law. ${ }^{41}$ The legislature does not need to confer specific authority on a tribunal such as the Energy Resources

Baker v. Canada (Minister of Citizenship and Immigration), [1999] 2 S.C.R. 817 [Baker] and more recently Health Services and Support - Facilities Subsector Bargaining Assn. v. British Columbia, 2007 SCC 27, [2007] 2 S.C.R. 391. In this case (which may signal a greater openness to international law at least at the highest levels), the plaintiff trade union sought to impugn the validity of provincial labour legislation that limited the union's collective bargaining rights on the grounds that it breached the plaintiff's right to freedom of association. The question for the Court, therefore, was whether freedom of association protected the right to engage in collective bargaining. Earlier decisions of the Court had concluded that freedom of association should not be so interpreted, but in this case the Court was persuaded to reverse that decision. The Court gave several reasons for reversing itself but one reason (at paras. 69-79) was that such an interpretation was consistent with Canada's obligations under three instruments: the ILO's Convention (No. 87) concerning freedom of association and protection of the right to organize, 9 July 1948, 68 U.N.T.S. 17; the ICCPR; and the International Covenant on Economic, Social and Cultural Rights, 16 December 1966, 993 U.N.T.S. 3 [ICESCR]. While none of these instruments explicitly declared that freedom of association included a right of collective bargaining, the Court took notice of the views of both the Human Rights Committee and various ILO committees and expert bodies to support that conclusion. The Court also emphasized that it was the current state of Canada's "international law commitments and the current state of international thought on human rights" that should provide "a persuasive source for interpreting the scope of the Charter" and, in particular, it should be interpreted as "recognizing at least the same level of protection" as that provided by international instruments to which Canada is a party (at paras. 78-79).

Bouzari, supra note 31 at para. 64 .

See Sioui, supra note 3.

Article 31(3)(c) of the Vienna Convention on the Law of Treaties, 23 May 1968, 1155 U.N.T.S. 331 [Vienna Convention], requires the interpreter of the treaty to take into account as part of the context for interpreting a treaty "any relevant rules of international law applicable in the relations between the parties." There is a long-standing tradition in international human rights law for the courts to take an evolutive approach to the interpretation of human rights instruments and this tradition has spilled over into other areas as well. This tradition is reflected in Awas Tingni, supra note 20 and the other decisions of the Inter-American Court discussed below, in jurisprudence of the International Court of Justice such as the Legal Consequences for States of the Continued Presence of South Africa in Namibia (South West Africa) Notwithstanding Security Council Resolution 276 (1970), Advisory Opinion, [1971] I.C.J. Rep. 16 at 31 and the Case Concerning Gabcikovo-Nagymoros Project (Hungary/Slovakia), [1997] I.C.J. Rep. 7, and in the jurisprudence the European Court of Human Rights. For a recent review see Duncan French, “Treaty Interpretation and the Incorporation of Extraneous Legal Rules” (2006) 55 I.C.L.Q. 281. ${ }_{41}$ Paul v. British Columbia (Forest Appeals Commission), 2003 SCC 55, [2003] 1 S.C.R. 585; see also Law Society of New Brunswick v. Ryan, 2003 SCC 20, [2003] 1 S.C.R. 247. These authorities deal with the authority and the duty of tribunals to apply constitutional law but the principle is the same. 
Conservation Board or the National Energy Board before such a tribunal can take cognizance of international law matters. ${ }^{42}$

Interested parties also have access to international fora, specifically, for present purposes, the UN Human Rights Committee and the Inter-American Commission on Human Rights, but subject in each case to the prior exhaustion of domestic remedies. ${ }^{43}$ The UN Human Rights Committee is established by art. 28 of the ICCPR. It has standing jurisdiction (as per art. 40) to consider the regular reports filed by contracting parties with respect to "measures [those parties] have adopted which give effect to the rights recognized herein and on the progress made in the enjoyment of those rights." 44 In addition, the Committee can consider communications from individuals "claiming to be victims of violations of any of the rights set forth in the Covenant" with respect to those states that ratify the Optional Protocol to the International Covenant on Civil and Political Rights. ${ }^{45}$ Canada has ratified the Optional Protocol. The "views" of the Committee with respect to individual petitions are not formally binding on the states concerned in the same manner as, say, a judgment of the International Court of Justice. However, they do represent the considered opinion of recognized jurists with respect to the application of the relevant law to the particular facts. ${ }^{46}$

The Inter-American Commission on Human Rights was first established in 1959 by resolution of the member states of the OAS and became permanent as a result of an amendment to the Charter of the Organization of American States in $1967 .{ }^{47}$ The Commission's procedure is elaborated by Part II of the American Convention. Individuals may lodge petitions with the Commission. ${ }^{48}$ In addition to considering petitions from time to time, the Commission issues so-called “country reports” on the human rights situations in various countries. Many of these reports contain chapters that focus on the situation of indigenous peoples. $^{49}$

\section{$42 \quad$ See Baker, supra note 37.}

$43 \quad$ See discussion of exhaustion of local remedies, infra note 59.

$44 \quad$ ICCPR, supra note 13, art. 40(1).

45 GA Res. 63/117, UN GAOR, 2008, UN Doc. A/63/435, Preamble [Optional Protocol]. The Optional Protocol was adopted at the same time as the ICCPR, ibid.

46 See ICCPR, ibid., art. 28(2). Persons appointed (18 members) shall be "persons of high moral character and recognized competence in the field of human rights.”

47 OAS, Ninth International Conference of American States, Charter of the Organization of American States, OR OEA/Ser.G.c.P/INF.3964/96, rev. 1 (1948) [OAS Charter]. See Anaya, supra note 29 at 232. Petitions may allege breach of the American Convention; art. 43 of the Convention establishes this for the purposes of the Convention. The Commission claims a broader jurisdiction with respect to the Declaration, see below. In Aurelio Cal, supra note 25 at paras. 21-22, the Court commented on a Commission report in response to the petition of the Maya Indigenous Communities (discussed below).The Court noted that the proceedings were not proceedings to enforce the findings of the Commission and did not bind the Court; nevertheless the Court could not be oblivious to the findings of the Commission and may find them to be persuasive where cogently argued.

49 Anaya, supra note 29 at 232-34; a useful compilation is the Commission's general note: OAS, InterAmerican Commission on Human Rights, Human Rights Situation of the of Indigenous People in the Americas, OR OEA/Ser.L/V/II.108/Doc.62 (2000). This contains a general discussion as well as extracts from earlier decisions including Yanomani Indians v. Brazil (1985), Inter-Am. Comm. H.R. No. 7615, Annual Report of the Inter-American Commission on Human Rights: 1984-1985, OEA/Ser.L/V/II.66/doc.10 rev.1 (1985) 24. 


\section{The International Covenant on Civil and Political Rights}

This section of the article examines art. 27 and art. 1 of the ICCPR.

\section{A. Article 27 of the International Covenant on CIVIL AND POLITICAL Rights}

Article 27 provides as follows: "In those States in which ethnic, religious or linguistic minorities exist, persons belonging to such minorities shall not be denied the right, in community with the other members of their group, to enjoy their own culture, to profess and practise their own religion, or to use their own language."

Article 27 deals with the rights of minorities. It does not specifically recognize the rights of indigenous peoples. However, it is clear that the article does speak to the situation of indigenous peoples to the extent that they may bring themselves within its terms. ${ }^{51}$ The article addresses the rights of minorities in relation to culture, religion, and language. In the context of the effects of resource development on indigenous peoples, the UN Human Rights Committee has directed most of its attention to the right to culture and to the material aspects of culture that are founded on the close connection between an indigenous people and a particular territory. ${ }^{52}$

The UN Human Rights Committee has adopted a General Comment on the implementation of art. $27^{53}$ and the Committee has also made a number a number of decisions in response to individual communications with respect to alleged breaches of art. $27 .{ }^{54} \mathrm{~A}$ number of these cases have involved resource development within the traditional territories of indigenous peoples.

Martin Scheinin (a former member of the Human Rights Committee) puts the point this way: “indigenous groups that are in a 'minority situation', i.e. subject to a greater or lesser degree of dispossession or subordination by another now dominant group, are entitled to protection as minorities under ICCPR article 27": see Martin Scheinin, "Indigenous Peoples' Land Rights Under the International Covenant on Civil and Political Rights" (Paper prepared for Torkel Oppsahls minneseminar, Norwegian Centre for Human Rights, University of Oslo, 28 April 2004) at 2, online: Gáldu <http://www.galdu.org/govat/doc/ind_peoples_land_rights.pdf $>$.

52 That said, it is possible to imagine that an indigenous people would also be able to maintain claims based on religion (see e.g. the discussion of the connection between land and religion in Awas Tingni, supra note 20 and especially the joint separate concurring opinion of Judges Cancçado Trindade, Pacheco Goómez, and Abreu-Burelli) and even language (the naming of territory and places within the territory). General Comment No. 23: The rights of minorities (Art. 27), 50th Sess., UN Doc. CCPR/C/21/Rev.1/ Add.5 (1994) [General Comment No. 23]. As with Committee decisions or views, these General Comments are not binding on the Committee or parties to the relevant treaty but they do represent a distillation of the Committee's views on particular articles.

54 The Committee can only consider communications involving an alleged breach of the right of individuals. In both its General Comment No. 23 and in a series of decisions the Committee has emphasized that it will not take cognizance of a breach of art. 1 that affirms and protects the rights of peoples. For a recent decision reiterating this position see Human Rights Committee, Views of the Human Rights Committee under article 5, paragraph 4, of the optional protocol to the International Covenant on Civil and Political Rights (Communication No. 760/1997, submitted by J.G.A. Diergaardt et al.), UN HRCOR, 69th Sess., UN Doc. CCPR/C/69/D/76/1997 (2000) at para. 10.3 [Diergaardt]. The committee will comment on art. 1 in the context of its so-called "concluding observations" with respect to state reports filed pursuant to art. 40 of the Convention: see Scheinin, supra note 51 at 10 . 


\title{
B. The Human Rights Committee's General Comment on Article 27
}

For present purposes, it is important to emphasize three aspects of General Comment No. 23. First, as hinted at above, the Committee has chosen to emphasize that the right to culture may entail a connection between a member or members of a minority and a particular territory.

\begin{abstract}
3.2. The enjoyment of the rights to which article 27 relates does not prejudice the sovereignty and territorial integrity of a State party. At the same time, one or other aspect of the rights of individuals protected under that article - for example, to enjoy a particular culture - may consist in a way of life which is closely associated with territory and use of its resources. This may particularly be true of members of indigenous communities constituting a minority. ${ }^{55}$
\end{abstract}

In other words, that connection with land may be a protected right within the meaning of art. 27. The Comment continues:

7. With regard to the exercise of the cultural rights protected under article 27, the Committee observes that culture manifests itself in many forms, including a particular way of life associated with the use of land resources, especially in the case of indigenous peoples. That right may include such traditional activities as fishing or hunting and the right to live in reserves protected by law. ${ }^{56}$

Second, the Committee has emphasized that the negative framing of the article will not excuse the state from inaction. In particular, the state may be required to take positive measures of protection to ensure that members of minorities and indigenous peoples are not denied their protected rights and their opportunity to practise them. ${ }^{57}$ And third, the Committee suggested that the right should be interpreted as having participatory and procedural content. Thus, "[t]he enjoyment of those rights may require positive legal measures of protection and measures to ensure the effective participation of members of minority communities in decisions which affect them." 58

55 General Comment No. 23, supra note 53 at para. 3.2. Subsequently, in Diergaardt, ibid., the Committee had to consider an art. 27 denial of access to culture case that was brought by the Rehoboth Baster Community (descendants of the indigenous Kohi and Afrikaans, who had lived in that particular territory since 1872). The Committee rejected the claim of exclusive pasturing access to certain lands on the basis that the community's connection with the land "is not the result of a relationship that would have given rise to a distinctive culture" and further while the community had been able to demonstrate distinctive elements of self-government it had "failed to demonstrate how these factors would be based on their way of raising cattle” (at para. 10.6). See also the individual concurring opinion of Evatt and Medina Quiroga emphasizing that the claim was an economic rather than a cultural claim "and does not draw the protection of article 27"(ibid.) General Comment No. 23, ibid. at para. 7.

Ibid. at para 6.1:

Although article 27 is expressed in negative terms, that article, nevertheless, does recognize the existence of a "right" and requires that it shall not be denied. Consequently, a State party is under an obligation to ensure that the existence and the exercise of this right are protected against their denial or violation. Positive measures of protection are, therefore, required not only against the acts of the State party itself, whether through its legislative, judicial or administrative authorities, but also against the acts of other persons within the State party.

And at 6.2: "Accordingly, positive measures by States may also be necessary to protect the identity of a minority and the rights of its members to enjoy and develop their culture and language and to practise their religion, in community with the other members of the group." Ibid. at para 7. 


\section{Human Rights Committee Decisions on Article 27: THE JURISPRUDENCE}

Of those cases that have been deemed admissible under art. $27^{59}$ and in which the petitioner is an indigenous person or a group of indigenous people, ${ }^{60}$ a large number have dealt with allegations that the state has breached the petitioner's art. 27 rights by authorizing resource development activities in the traditional territory of an indigenous people. These decisions include the Lubicon case (Canada) ${ }^{61}$ and the three Länsman cases (Finland) ${ }^{62}$ Although the petitioner was successful in the Lubicon case, the decision is one of the most problematic for a number of reasons. First, the petitioner and the state were never able to come close to agreeing on the facts. Second, the petitioner's claims were very broadly drafted. And third (perhaps because of the first two problems), the Committee's reasoning in support of its conclusion is, to say the least, very thin.

While the facts, which principally related to a ten-year period from the early to mid-1970s to the mid-1980s, were highly contested, it seems possible to provide the following summary. The Lubicon Cree Band claimed a traditional territory in the Peace District of Alberta. The Band was relatively isolated and members were heavily dependent on their ability to access wildlife and other resources for their sustenance and for cultural purposes. In the domestic courts, the Band claimed that it had an aboriginal title to this territory, or, in the alternative, that it was entitled to have a reserve set apart for it under the terms of Treaty No. $8{ }^{63}$ The Band's efforts to file a caveat against Crown lands was thwarted when the Province of

The principal admissibility issue is typically exhaustion of local remedies. The Committee takes the view that where the general issue has already been decided by the highest domestic tribunal the particular petitioners need not themselves pursue these avenues: see Human Rights Committee, Views of the Human Rights Committee under article 5, paragraph 4, of the Optional Protocol to the International Covenant on Civil and Political Rights (Communication No. 24/1977, submitted by Sandra Lovelace), UN HRCOR, 13th Sess, UN Doc. CCPR/C/13/D/24/1977 (1981) at 166 [Lovelace]; Human Rights Committee, Views of the Human Rights Committee under article 5, paragraph 4 of the Optional Protocol to the International Covenant on Civil and Political Rights (Communication No. 511/1992, submitted by Ilmari Länsman et al.), UN HRCOR, 52d Sess., UN Doc. CCPP/C/52/D/511/1992 (1994) at para. 6.2 [Länsman \# 1]. There is also an interesting discussion on exhaustion of local remedies in Human Rights Committee, Views of the Human Rights Committee under article 5, paragraph 4, of the Optional Protocol to the International Covenant on Civil and Political Rights (Communication No. 1023/2001, submitted by Jouni Länsman, Eimo Länsman and the Muotkatunturi Herdsmen's Committee), UN HRCOR, 83d Sess., UN Doc. CCPR/C/83/DR/1023/2001 (2005) at paras. 6.1-6.6 [Länsman \# 3]. The petitioners had not commenced any new actions in domestic courts before presenting this petition. The Committee thought that some geographical areas included in the petition were covered by the previous actions but others were perhaps new and as a result were declared inadmissible (at para. 6.5).

60 The Committee has emphasized (see especially Human Rights Committee, Views of the Human Rights Committee under article 5, paragraph 4, of the Optional Protocol to the International Covenant on Civil and Political Rights (Communication No. 16711984, submitted by Chief Bernard Ominayak and the Lubicon Lake Band), UN HRCOR, 38th Sess., UN Doc. CCPR/C/38/D/167/1984 (1990) at para. 32.1 [Lubicon]) that it has no jurisdiction under the Optional Protocol to pass on the rights of peoples under art. 1 but it does have jurisdiction with respect to alleged breaches of part III of the ICCPR, arts. 6-27 inclusive and there can be "no objection to a group of individuals, who claim to be similarly affected, collectively to submit a communication about alleged breaches of their rights." Ibid.

62 For Länsman \# 1 and Länsman \# 3 see supra note 59, and for Länsman \# 2 see Human Rights Committee, Views of the Human Rights Committee under article 5, paragraph 4, of the Optional Protocol to the International Covenant on Civil and Political Rights (Communication No. 671/1995, submittted by Jouni E. Länsman et al.), UN HRCOR, 58th Sess., UN Doc. CCPR/C/58/D/671/1995 [Länsman \# 2].

$63 \quad 21$ June 1899 (Ottawa: Queen’s Printer and Controller of Stationery, 1966). For the domestic litigation see Ominayak v. Norcen Energy Resources Ltd. (1985), 58 A.R. 161 (C.A.). I commented on this decision at the time in Nigel Bankes, "Judicial Attitudes to Aboriginal Resource Rights and Title” (1985) 13 Resources 1. 
Alberta amended the Land Titles $A c t^{64}$ to prevent any person from filing a caveat against unpatented Crown land. ${ }^{65}$

The Province of Alberta, taking the view that the lands in question were unencumbered Crown lands, issued numerous resource dispositions within the territory claimed by the Lubicon for both oil and gas and forestry purposes. These resource activities and associated activities, such as access and seismic, must clearly have had some effect on wildlife populations on which the Lubicon Cree depended, but the seriousness of those impacts was much contested. The Lubicon did commence actions in the domestic courts but efforts to seek interlocutory relief were not successful. ${ }^{66}$ There is some evidence to the effect that the Province was reluctant to engage in negotiations with the Lubicon about setting aside a reserve for the Band (or to confirm an earlier land survey for a reserve), but later the Province did soften its position and there were several federal attempts at negotiation both directly and through a facilitator, E. Davie Fulton. Other bands also claimed reserves and traditional territory in the same area. During the proceedings, Canada argued that it was making considerable good faith efforts to negotiate a solution to the Lubicon's request for reserve lands and that its proposals met standards of fairness based on "recent settlements with native groups, and ... the legitimate social and economic objectives of the Band." ${ }^{67}$ The Band contested these claims and argued in turn that Canada was trying to break up the Band by negotiating agreements with elements of the Band. ${ }^{68}$

The principal claim of the applicants was that Canada was in breach of art. 1 of the ICCPR. The Committee concluded that it could not take cognizance of a claim based on art. 1 as part of its optional protocol jurisdiction, ${ }^{69}$ but it did take the view that "the facts as submitted might raise issues under other articles of the Covenant including article 27" and then proceeded on that basis. ${ }^{70}$

In light of the multiple competing submissions of the parties, it was hardly surprising that the Committee concluded that "the persistent disagreement between the parties as to what constitutes the factual setting for the dispute at issue has made the consideration of the claims on the merits most difficult." ${ }^{, 11}$ Nevertheless, the Committee also felt able to conclude that

$64 \quad$ R.S.A. 2000 , c. L-4.

65 Land Titles Amendment Act, S.A. 1977, c. 27, s. 10 and for the Hansard discussion see Legislative Assembly, Alberta Hansard, No. 31 (13 April 1977) at 1206-19 (Hon. Gerard Amerongen).

Supra note 60.

Lubicon, supra note 60 at para. 21.3. See also paras. 171.1, 19.1, 21.1-21.3, 26.8.

Ibid. at paras. 24.1, 27.5.

Ibid. at paras. 13.3, 32.2.

Ibid. at para. 13.4. The Committee also noted that "there is no doubt that many of the claims presented raise issues under article 27 . The Committee recognizes that the rights protected by article 27, include the rights of persons, in community with others, to engage in economic and social activities which are part of the culture of the community to which they belong” (at para. 32.2). In response to that the Band did provide additional submissions arguing that Canada's conduct also amounted to a breach of arts. 6 , 7, 14(1), 17, 18(1), 23(1), 26 of the ICCPR.

71 Lubicon, ibid. at para. 30; see also para. 29.5. See also Human Rights Committee, Views of the Human Rights Committee under article 5, paragraph 4, of the Optional Protocol to the International Covenant on Civil and Political Rights (Communication No. 879/1999, submitted by George Howard), UN HRCOR, 84th Sess., UN Doc. CCPR/C/84/D/879/1999. Mr. Howard (a member of the Hiawatha community, Mississauga First Nation) alleged that Canada breached art. 27 by restricting his right to fish for food. The Committee noted that the parties disagreed as to some of the factual issues in the cases including the question of whether or not Howard had sufficient access to fish resources to maintain his culture and on that basis concluded that the information before it was inadequate to justify a finding of violation (at para. 12.11). 
[h]istorical inequities, to which the State party refers, and certain more recent developments threaten the way of life and culture of the Lubicon Lake Band, and constitute a violation of article 27 so long as they continue. The State party proposes to rectify the situation by a remedy that the Committee deems appropriate within the meaning of article 2 of the Covenant. ${ }^{72}$

This reasoning is cryptic in the extreme. The "historical inequities" would seem to refer to the fact that the Band lacked a reserve. ${ }^{73}$ The "recent developments" likely refer to state authorized resource activities and developments in Lubicon territory, while the proposed efforts to rectify the situation must refer to Canada's proposed settlement. ${ }^{74}$

In sum, while the Lubicon case is correctly cited as an example of the Committee concluding that a contracting party was in breach of its art. 27 obligations, the "precedential" takes us from the premises to the conclusions.

\section{THE LÄNSMAN DECISIONS}

All three Länsman decisions involved state authorized resource activities on lands to which the Sami reindeer herders made some claim of traditional connection, although, as it was put in Länsman \# 1, "the question of ownership of lands traditionally used by the Samis is disputed between the Government and the Sami community."76 All three cases involved reindeer herding activities. A common feature of the first two cases was that the petitioners had explicitly invoked art. 27 in the domestic proceedings in which they engaged as part of exhausting local remedies. ${ }^{77}$ The first case focused on a quarrying operation, the second and third focused on logging operations.

The decision in Länsman \#1 (in 1994) involved state authorization of a quarrying project and associated transportation activities. The petitioners had three main concerns with respect to the project: (1) that the quarrying and transport would disrupt herding activities and the complex system of reindeer fences; (2) that the transportation route would run next to a slaughterhouse for reindeer that had to meet strict export rules; and (3) that the site of the quarry was "a sacred place of the old Sami religion."78 The petitioners alleged that that these

Lubicon, ibid. at para. 33.

In support of this see ibid. at para. 24.1 (recording Canada's concession to the effect that "the Lubicon Lake Band has suffered a historical inequity and ... they are entitled to a reserve and related entitlements").

The latter does of course beg the question as to which of the many settlements discussed in the decision the Committee might be referring to.

The quotation marks simply connote that the Committee has no formal doctrine of precedent. That said, the Committee, as with other international tribunals and similar bodies, routinely cites previous decisions to support its conclusions, but the real value of these decisions must depend on the quality of the reasoning that they exhibit. Note as well that the Committee has expressed concern fairly recently (2006) that negotiations between Canada and the Lubicon are deadlocked: see Human Rights Committee, Consideration of Reports Submitted by States Parties Under Article 40 of the Covenant, Concluding Observations of the Human Rights Committee, Canada, UN HRCOR, 85th Sess., UN Doc. CCPR/C/CAN/CO/5 (2006) at para. 9.

Länsman \# 1, supra note 59 at paras. 2.2, 7.1; Länsman \# 2, supra note 62 at para. 2.2; Länsman \# 3, supra note 59 at para. 7.4.

See Länsman \# 1, ibid. at para. 2.7; Länsman \# 2, ibid. at paras. 2.8-2.9, 6.1-6.4 where Finland observes that the Covenant is incorporated into domestic law and "directly applicable before all Finnish authorities" (at para. 6.4). The petitioners did not initiate any new domestic proceedings in relation to Länsman \# 3, ibid. (see para. 4.5 of that decision). Lansman \# 1, ibid. at para 2.6. 
activities taken together would violate their art. 27 rights and "in particular their right to enjoy their own culture, which has traditionally been and remains essentially based on reindeer husbandry."79

In its response, Finland conceded that the concept of culture in art. 27 extended to "reindeer herding as 'an essential component of the Sami culture," "80 but argued either that the impacts of the activities (to date or proposed) were not significant, or that art. 27 had been fully considered and applied by domestic authorities and that there should be a margin of discretion afforded to those domestic authorities. ${ }^{81}$ With respect to the first, Finland emphasized the small area that would be used for quarrying especially in light of the size of the entire area used by the herders for their activities. Finland also emphasized that it had imposed terms and conditions on the permitted activities that were designed to minimize the impact of those activities on reindeer herding activities.

The Committee dismissed the petition. The Committee accepted the substantive basis of the petition (the right to culture) and noted that the petitioners could maintain their claim even though they had already adapted their methods of husbandry in response to changing conditions. $^{82}$ The Committee also took the view that the state was not entitled to the benefit of a margin of appreciation. ${ }^{83}$ The real issue for the Committee was to assess the obligations that the state had undertaken in art. 27. Once that was understood, it would be possible to assess "[t]he scope of its freedom ... to encourage development or allow economic activity by enterprises." 84 The Committee's interpretation emphasizes that the state's duty is a duty not to deny the members of a minority their right to culture. Accordingly,

[a]rticle 27 requires that a member of a minority shall not be denied his right to enjoy his culture. Thus, measures whose impact amount to a denial of the right will not be compatible with the obligations under article 27. However, measures that have a certain limited impact on the way of life of persons belonging to a minority will not necessarily amount to a denial of the right under article $27^{85}$

The question ... is whether the impact of the quarrying on Mount Riutusvaara is so substantial that it does effectively deny to the authors the right to enjoy their cultural rights in that region. ${ }^{86}$

[T]he Committee concludes that quarrying ... in the amount that has already taken place, does not constitute a denial of the authors' right, under article 27, to enjoy their own culture. It notes in particular that the interests of the Muotkatunturi Herdsmens' Committee and of the authors were considered during the proceedings leading to the delivery of the quarrying permit, that the authors were consulted during the proceedings, and that reindeer herding in the area does not appear to have been adversely affected by such quarrying as has occurred. $^{87}$

Ibid. at para. 3.1.

Ibid. at para. 7.3.

Ibid. at para. 7.13.

Ibid. at para. 9.3.

Ibid. at para. 9.4. This must mean that the Committee itself will decide whether or not the state is in breach of the standard imposed by art. 27. In standard of review terms this means that there is (in theory) no deference and that the standard of review is correctness.

Ibid.

Ibid. [emphasis added].

Ibid. at para. 9.5.

Ibid. at para. 9.6 [emphasis in original]. 
The Committee went on to note that permit terms and conditions were designed to minimize the impact of quarrying activities on herding activities. But the Committee also warned that future economic activities authorized by the state would need to be carried out in a manner that would allow the authors to

continue to benefit from reindeer husbandry. [And] if mining activities in the Angeli area were to be approved on a large scale and significantly expanded by those companies to which exploitation permits have been issued, then this may constitute a violation of the authors' rights under article 27, in particular of their right to enjoy their own culture. The State party is under a duty to bear this in mind when either extending existing contracts or granting new ones. ${ }^{88}$

It bears emphasizing that although the Committee suggested that the state was not entitled to the benefit of a margin of appreciation, the Committee took account of the fact that the state did consult the petitioners about the project, their concerns, and the potential impact of the project. In other words, these were the methods chosen by the state to reach its own conclusion that the relevant threshold had not been reached, and in practice the Committee does seem to have given that conclusion some independent weight.

Länsman \# $2^{89}$ involved the same general geographic area but the resource activity that triggered this petition was logging and associated infrastructure. This time, the particular concern of the petitioners was that the proposed logging activities would affect winter grazing areas. These areas were of particular importance because only 20 percent, or some 31,000 hectares, of the 255,000 hectares of traditional territory were suitable for winter herding, and the proposed logging activities would affect some 3,000 hectares of those lands. ${ }^{90}$ Furthermore, the Committee summarized:

\footnotetext{
The authors observe that the area in question consists of old untouched forests, which means that both the ground and the trees are covered with lichen. This is of particular importance due to its suitability as food for young calves and its utility as “emergency food" for elder reindeer during extreme weather conditions.... [And] female reindeer give birth to their calves in the disputed area during springtime, because the surroundings are quiet and undisturbed. ${ }^{91}$
}

Finland's response drew heavily on the Committee's views in Lansman \# 1. Finland also chose to emphasize that the issues (including art. 27) had been carefully considered by the domestic decision-makers and the courts, that the relevant authorities favoured manual logging techniques rather than clear cuts, and that the herdsmen's association had been fully consulted. ${ }^{92}$

In the end, the Committee once again rejected the petition, holding that the activities complained of had not crossed the threshold of denying access to the material aspects of culture:

Ibid. at para. 9.8 [emphasis in original].

Supra note 62.

Ibid. at para. 2.1

Ibid. at para. 2.4.

See generally ibid. at paras. 6, 8 . 
It is uncontested that the Muotkatunturi Herdsmen's Committee, to which the authors belong, was consulted in the process of drawing up the logging plans and in the consultation, the Muotkatunturi Herdsmen's Committee did not react negatively to the plans for logging. That this consultation process was unsatisfactory to the authors and was capable of greater interaction does not alter the Committee's assessment. It transpires that the State party's authorities did go through the process of weighing the authors' interests and the general economic interests in the area specified in the complaint when deciding on the most appropriate measures of forestry management, i.e. logging methods, choice of logging areas and construction of roads in these areas. The domestic courts considered specifically whether the proposed activities constituted a denial of article 27 rights. The Committee is not in a position to conclude, on the evidence before it, that the impact of logging plans would be such as to amount to a denial of the authors' rights under article 27 or that the finding of the Court of Appeal affirmed by the Supreme Court, misinterpreted and/or misapplied article 27 of the Covenant in the light of the facts before it. ${ }^{93}$

[T] he State party's forestry authorities have approved logging on a scale which, while resulting in additional work and extra expenses for the authors and other reindeer herdsmen, does not appear to threaten the survival of reindeer husbandry. ${ }^{94}$

The Committee considers that if logging plans were to be approved on a scale larger than that already agreed to for future years in the area in question or if it could be shown that the effects of logging already planned were more serious than can be foreseen at present, then it may have to be considered whether it would constitute a violation of the authors' right to enjoy their own culture within the meaning of article 27 . The Committee is aware, on the basis of earlier communications, that other large scale exploitations touching upon the natural environment, such as quarrying, are being planned and implemented in the area where the Sami people live. Even though in the present communication the Committee has reached the conclusion that the facts of the case do not reveal a violation of the rights of the authors, the Committee deems it important to point out that the State party must bear in mind when taking steps affecting the rights under article 27, that though different activities in themselves may not constitute a violation of this article, such activities, taken together, may erode the rights of Sami people to enjoy their own culture. ${ }^{95}$

In Länsman \# 3, the petitioners again sought to argue that the threshold set by the earlier jurisprudence on art. 27 had been reached in this instance as a result of ongoing logging operations. The petitioners once again focused on the importance of winter habitat, but also emphasized that the government itself had decided to reduce herd numbers on the basis that the carrying capacity of the area had been reduced (which the petitioners attributed to loss of horsehair lichen pasture due to logging operations). ${ }^{96}$ The state in turn emphasized the small area in which logging operations were occurring in relation to the entire herding area and suggested that there were other reasons for the decision to limit herd size, including previous overstocking. ${ }^{97}$

In its decision, the Committee emphasized the importance of considering the cumulative effects of various state authorized activities on the ability of members of the minority to enjoy their own culture:

Ibid. at para. 10.5 [emphasis in original].

Ibid. at para. 10.6.

Ibid. at para. 10.7 [emphasis added].

Lansman \# 3, supra note 59 at para. 3.4.

Ibid. at paras. 7.7-7.10. 
In weighing the effects of logging, or indeed any other measures taken by a State party which has an impact on a minority's culture, the Committee notes that the infringement of a minority's right to enjoy their own culture, as provided for in article 27, may result from the combined effects of a series of actions or measures taken by a State party over a period of time and in more than one area of the State occupied by that minority. Thus, the Committee must consider the overall effects of such measures on the ability of the minority concerned to continue to enjoy their culture. In the present case, and taking into account the specific elements brought to its attention, it must consider the effects of these measures not at one particular point in time either immediately before or after the measures are carried out — but the effects of past, present and planned future logging on the authors' ability to enjoy their culture in community with other members of their group. $^{98}$

The Committee acknowledged that the matter was not easy to assess given that the parties "disagree on the effects of logging in the areas in question." ${ }^{99}$ However, in the end, the Committee concluded once again that there was no breach of art. 27. The Committee noted that "the overall number of reindeers still remains relatively high" and that "the effects of logging carried out in the Pyhäjärvi, Kirkko-outa and Paadarskaidi areas have not been shown to be serious enough as to amount to a denial of the authors' right to enjoy their own culture in community with other members of their group under article 27 of the Covenant."100

There are a number of other Committee decisions on art. 27 that deal with the rights of indigenous peoples. These decisions deal with such matters as the right not to be excluded by government action from living in community with other members of an indigenous minority ${ }^{101}$ and an agreement pursuant to which traditional fishing rights were replaced by an agreement affording parties access to a share of a commercial fishery. ${ }^{102}$ These decisions do not speak directly to the potential conflict between the right of indigenous peoples to culture and government authorized resource development in the traditional territories of indigenous peoples.

\section{E. ConClusions WITH RESPECt TO ARTICLE 27}

The right to culture protected by art. 27 may include, in an appropriate case, the right to maintain a connection with a particular territory and a particular way of life. The article does not protect a minority from any interference with a connection with a particular territory, but it does protect the minority from serious interference (whether singly or cumulatively) that amounts to the denial of the opportunity to maintain a connection with a particular territory and therefore the denial of the right to culture.

While the Committee has suggested that the state is afforded no margin of appreciation in its assessment of the violation of protected rights, as a matter of practice, the Committee

Ibid. at para. 10.2.

Ibid. at para. 10.3 .

Ibid.

Lovelace, supra note 59.

Human Rights Committee, Views of the Human Rights Committee Under Article 5, paragraph 4, of the Optional Protocol to the International Covenant on Civil and Political Rights (Communication No. 547/1993, submitted by Apirana Mahuika et al.), UN HRCOR, 70th Sess., UN Doc. CCPR/C/70/D/547/1993 (2000). I have discussed this decision in detail in Bankes, "Land Claim Agreements," supra note 16. 
does seem reluctant to interfere with state decision-makers, including the courts. This is most evident where the state can demonstrate that the relevant decision-makers turned their mind to the precise question of whether or not the proposed action might bring about a denial of access to culture and did so in a consultative manner. Whether stated as an absence of evidence of denial of culture, or as deference to national decision-makers, the Committee is reluctant to interfere unless that decision is, in some sense, unreasonable. However, the matter might well be different if the state is forced to defend a regulatory decision where there is no evidence that the decision-maker turned its mind to the relevant provision of the $I C C P R$ and the relevant test.

It is perhaps useful to conclude this section with some reflections on the threshold established by art. 27 in comparison with similar concepts in domestic law. The art. 27 threshold is high. This flows from the negative formulation of the duty, that is, the state's duty is a duty not to deny access to culture. This is a higher threshold than one finds in some domestic treaty formulations, most notably those treaty formulations that affirm a right to culture or to a particular cultural practice without qualifying that right with a competing power of the Crown, for example, the right to take up lands. Examples include the free exercise of religion and customs (discussed in Sioui ${ }^{103}$ ) and the Douglas Treaties ${ }^{104}$ in relation to fisheries (discussed in Saanichton ${ }^{105}$ ). In both cases (and the reasoning is supported in part by s. 88 of the Indian $A c t^{106}$ ), the positive formulation of the treaty right helped lower the threshold for determining breach and in each case the treaty right effectively trumped or precluded the application of the otherwise applicable provincial law (a law and permit authorizing a marina development in Saanichton, and the provincial Parks Act ${ }^{107}$ in Sioui).

But, in other cases (and here I think of the numbered treaties), the treaty right itself is qualified by the Crown's power to take up lands and, with that, the Crown's power to reduce the geographical ambit of the hunting right. This seems to have at least two legal consequences in domestic law. First, the government's power to move land from one category to another may trigger the duty to consult ${ }^{108}$ and second (but this is far from settled), there may be a substantive limit on the power of the Crown to take up lands. It is this second element that bears some analytical resemblance to the art. 27 duty not to deny access to culture. We can see this in the various efforts of the courts to express this limit. ${ }^{109}$ For example, Southin J. in Halfway River First Nation v. British Columbia (Ministry of Forests) put it this way:

Supra note 3.

See “Douglas Treaties: 1850-1854,” online: British Columbia Ministry of Aboriginal Relations and Reconciliation <http://www.gov.bc.ca/arr/treaty/landmark/douglas/default.html>.

Saanichton Marina Ltd. v. Tsawout Indian Band (1989), 57 D.L.R. (4th) 161 (B.C.C.A.) [Saanichton] (regarding the liberty to carry on their fisheries as formerly).

R.S.C. 1985 , c. I-5.

R.S.Q., c. P-9.

See Mikisew Cree, supra note 3.

I have explored this idea further in Nigel Bankes, “The Lands Taken Up Provision of the Prairie Treaties” in Henry Epp, ed., Access Management: Policy to Practice, Proceedings of the Conference Presented by the Alberta Society of Professional Biologists, Calgary, 18-19 March 2003, (Calgary: Alberta Society of Professional Biologists, 2004) 53. 
But if the Crown did grant all the lands away, it might be argued with some force that it had made the reservation nugatory. One might apply the common law doctrine of derogation from a grant, by analogy, to such a state of affairs.

The question in such an action would be whether what the Crown has done throughout the Halfway River First Nation's traditional lands by taking up land for oil and gas production, forestry, and other activities has so affected the population of game animals as to make the right of hunting illusory. "To make the right of hunting illusory" may be the wrong test. Perhaps the right test is "to impair substantially the right of hunting" or some other formulation of words. ${ }^{110}$

And Rothstein J. (as he then was) in the Federal Court of Appeal in Mikisew Cree First Nation v. Canada (Minister of Canadian Heritage) put it this way in terms of the substantive limits on the rights to take up land:

In considering Treaty 8 in context, Cory J. concluded [in Badger ${ }^{111}$ ] that the Indians "understood that land would be taken up and occupied in a way which precluded hunting, when it was put to a visible use that was incompatible with hunting." Unless the Crown has taken up land in bad faith or taken so much that no meaningful right to hunt remains, taking up land for a purpose express or necessarily implied in the treaty itself does not infringe a treaty right. ${ }^{112}$

The idea that there is a substantive limit to the Crown's power to take up land is an emerging principle in the jurisprudence on the numbered treaties. The threshold will be difficult to frame. At the very least, the art. 27 jurisprudence supports the proposition that a threshold is necessary. However, it may be argued that a more purposive reading of the numbered treaties will suggest a different threshold. I do not propose to make that argument here. It is sufficient for present purposes to emphasize that the continued taking up of lands may, at some point, breach both a First Nation treaty and art. 27 of the ICCPR. but the majority focused on the duty to consult rather than the substantive limits to "taking up."

1122004 FCA 66, [2004] 3 F.C. 436 at 440-41 [emphasis added]. Justice Rothstein (Sexton J.concurring) gave the majority judgment in the Court of Appeal, holding that the Crown was not in breach of any duty owed to the First Nation. The decision was overturned on appeal to the Supreme Court of Canada (supra note 3) where Binnie J.'s judgment turns on the duty to consult rather than on the substantive limits to the power to take up lands. 


\section{F. ARTiCle 1(2) OF THE COVENANTS AND THE DOCTRINE OF PERMANENT SOVEREIGNTY OVER NATURAL RESOURCES}

Article 27 of the ICCPR does not impose upon the state the duty to recognize the property and resource rights of minorities or indigenous people. While the state may have a positive duty to ensure that neither its actions, nor those of others, deny indigenous peoples the opportunity to enjoy their culture, ${ }^{113}$ art. 27 would, as Martin Scheinin suggests, "give support to indigenous title to land only in cases where it is proven that no other arrangement will meet this test." ${ }^{114}$ We must therefore look elsewhere for more positive affirmations of the land and resource rights of indigenous peoples. The obvious place to look, at least in the case of a state that is party to the ILO Convention 169, will be the terms of that Convention, specifically its arts. $12-14 .{ }^{115}$ Subsequent parts of this article examine the state's duty to delimit, demarcate, and title indigenous lands pursuant to the terms of the relevant InterAmerican instruments. But what about the balance of the ICCPR, and in particular, what about art. 1? The two Covenants (the ICCPR and the International Covenant on Economic, Social and Cultural Rights ${ }^{116}$ ) share a common art. 1 that recognizes the right of peoples to self-determination. Article 1 contains three paragraphs; it is the second paragraph that is the most important in this context. ${ }^{117}$ The first paragraph deals with core right of selfdetermination: "All peoples have the right of self-determination. By virtue of that right they freely determine their political status and freely pursue their economic, social and cultural development."118

For present purposes, we can simply say that most writers recognize that indigenous peoples may claim a right of self-determination under the terms of this article, although only in exceptional circumstances will this right entail a right of secession. ${ }^{119}$ In general, the right of self-determination for indigenous peoples must be worked out internally through arrangements of autonomy. The UN Human Rights Committee, in a series of "Concluding Observations" has clearly indicated that this is its understanding of the scope of art. $1 .^{120}$

Paragraph 2 of art. 1 elaborates what Scheinin has termed the "resource dimension of selfdetermination": “All peoples may, for their own ends, freely dispose of their natural wealth and resources without prejudice to any obligations arising out of international economic cooperation, based upon the principle of mutual benefit, and international law. In no case may a people be deprived of its own means of subsistence."121

See General Comment No. 23, supra note 53 at para. 6.1.

Scheinin, supra note 51 at 7-8.

For a detailed analysis see Graver \& Ulfstein, supra note 6. See also the resource provisions of the United Nations Declaration on the Rights of Indigenous Peoples, supra note 10, especially arts. 26-32. ICESCR, supra note 37.

I discuss here the first two paragraphs. Paragraph 3 specifies a "solidarity” obligation, the duty to assist others in attaining self-determination.

ICESCR, supra note 37, art. 1(1).

Scheinin, supra note 51 at 2; see also Reference re Secession of Quebec, supra note 33.

See e.g. Human Rights Committee, Concluding Observations of the Human Rights Committee: Canada, UN HRCOR, 65th Sess., UN Doc. CCPR/C/79/Add.105 (1999) at para. 7; Human Rights Committee, Concluding Observations of the Human Rights Committee: Norway, UN HRCOR, 67th Sess., UN Doc. CCPR/C/79/Add.112 (1999) at para. 17.

Scheinin, supra note 51 at 10; ICESCR, supra note 37, art. 1(2). 
Scheinin further suggests that this clause, especially its last sentence, has been used "in support of land rights” arguments by indigenous people. ${ }^{122}$ But the language of the article begs a lot of questions. The first sentence of the clause is generally associated with the doctrine of permanent sovereignty over natural resources (even though it does not use that precise terminology) and the idea of economic self-determination as a necessary adjunct to political independence. The carefully nuanced language suggests that although "peoples" may have the right to control or to regain control of "their" resources, they cannot ignore existing entitlements ("without prejudice to any obligations arising out of international economic co-operation”) but precisely what that might mean in terms of prompt, adequate, and effective compensation in the event of an expropriation is left deliberately vague. ${ }^{123}$ The second sentence is evidently an appeal to the jus cogens status of the claim, ${ }^{124}$ an irrefutable entitlement to subsistence based on a people's access to "their" resources that nobody can contradict, an irreducible minimum economic entitlement. Like art. 27, this sentence is negatively framed but, as with that provision, it seems reasonable to think that the state is required to take positive measures ${ }^{125}$ to ensure within its territory that peoples, including indigenous peoples, are not deprived of their "own means of subsistence."126

Paragraph 2 of common art. 1 vests control over the disposition of resources in peoples and not in the state. This is hardly surprising given the subject and context of the two Covenants, namely human rights vis-à-vis the state, but it does contrast with more statist articulations of the doctrine of permanent sovereignty, which, over time, evolved to vest the right of permanent sovereignty in the state rather than in the people. ${ }^{127}$ The question for present purposes is the extent to which indigenous peoples can claim not only the benefit of art. 1(2) but also its associated principle of permanent sovereignty. As for art. 1(2) itself, the position seems fairly clear. The term "peoples" must have the same meaning in each paragraph of art. 1 and thus must include indigenous peoples for the purposes of para. 2 just as it does for para. 1. The extent to which indigenous people may also claim to be the beneficiaries of the doctrine of permanent sovereignty is more contentious, however, no doubt because that doctrine explicitly makes use of the language of sovereignty; language that has typically been reserved by states for their own use.

Scheinin, ibid. See also General Comment No. 12: The right to self determination of peoples (Art. 1), 21st Sess., UN Doc. CCPR/3/03/84 (1984) at para. 5, which notes that "[p]aragraph 2 affirms a particular aspect of the economic content of the right of self-determination.” The Comment was adopted in 1984 and unfortunately is rather brief and unenlightening.

The evolution of the drafting of this article and its connection to the doctrine of permanent sovereignty (see also the savings clauses, ICCPR, supra note 13, art. 47 and ICESCR, supra note 37, art. 25) is discussed in Nico Schrijver, Sovereignty over Natural Resources: Balancing Rights and Duties (Cambridge: Cambridge University Press, 1997).

A jus cogens norm is a peremptory norm that will trump an inconsistent treaty or customary norm: Vienna Convention, supra note 40, arts. 53, 64.

For the discussion in the context of art. 27 see General Comment No. 23, supra note 53.

ICCPR, supra note 13, art. 1(2); ICESCR, supra note 37, art. 1(2) [emphasis added].

In the seminal Permanent sovereignty over natural resources, GA Res. 1803 (XVII), UN GAOR, 17th Sess., Supp. No. 17, UN Doc. A/5217 (1962) 15, the right was vested in "peoples and nations” but by the time of the adoption of the Charter of Economic Rights and Duties of States, GA Res. 3281(XXIX), UN GAOR, 29th Sess., Supp. No. 31, UN Doc. A/9631 (1974) 50, art. 2 provided that: “1. Every State has and shall freely exercise full permanent sovereignty, including possession, use and disposal, over all its wealth, natural resources and economic activities.” For discussion see Schrijver, supra note 123. 
In a working paper prepared for the Sub-Commission on the Promotion and Protection of Human Rights of the former Commission on Human Rights, ${ }^{128}$ Erica-Irene Daes (the former Chairperson Rapporteur of the Working Group on Indigenous Populations), sought to address some of these concerns. In particular, she argued that the term sovereignty should not be understood as the supreme authority of an independent state but rather as "governmental control and authority," 129 and that, in any event, sovereignty is always in practice limited both by general international law and treaty obligations. Thus, for her there is no objection in principle to using the term sovereignty in connection with indigenous peoples. More functionally, she suggests that the label is not as important as "whether indigenous peoples' ownership of and governing authority over all their natural resources are adequately recognized and protected." 130 In conclusion, she suggests that international law has now reached the point where it recognizes the right of indigenous peoples to permanent sovereignty over their natural resources. She articulates this right as "a collective right by virtue of which the State is obligated to respect, protect, and promote the governmental and property interests of indigenous peoples (as collectivities) in their natural resources.”131

At this stage it is not possible to offer a more definitive reading of art. 1(2). Our understanding of its application to indigenous peoples continues to develop as does the general international law relating to indigenous peoples. The last sentence of the paragraph is clearer and does support the UN Human Rights Committee's reading of art. 27. ${ }^{132}$

\section{THE INTER-AMERICAN HUMAN RIGHTS SySTEM}

The OAS was created at the Ninth International Conference of American States at Bogota in 1948. The OAS Charter contains limited reference to human rights and does not specifically mention indigenous people. ${ }^{133}$ The Bogota Conference also saw the adoption of the American Declaration, ${ }^{134}$ followed in 1969 by the adoption of the American Convention. ${ }^{135}$ Canada did not join the OAS until 1990.

The institutions of the Inter-American system include the Inter-American Commission on Human Rights and the Inter-American Court of Human Rights. The formation of the Commission is discussed above. The Inter-American Court was created in 1969 by Part II of the American Convention. There is no general right of individual petition to the Court; cases may only be brought by another state or by the Commission, and only with respect to those states that are party to the Convention. ${ }^{136}$ The Commission has brought a number of

Erica-Irene A. Daes, Prevention of Discrimination and Protection of Indigenous Peoples: Indigenous people's permanent sovereignty over natural resources, UN ESCOR, 56th Sess., UN Doc. E/CN.4/Sub.2/2004/30 (2004).

Ibid. at para. 18.

Ibid. at para. 31 .

Ibid. at para. 40.

The Committee takes the view that it may use art. 1 to interpret art. 27: Diergaardt, supra note 54 at para. 10.3 ("the provisions of article 1 may be relevant in the interpretation of other rights protected by the Covenant, in particular articles 25, 26 and 27”). See also Scheinin, supra note 51.

Thornberry, supra note 29, c. 11 at 266-67ff.

Supra note 24.

Supra note 23. Adopted at the Inter-American Specialized Conference on Human Rights, San José, Costa Rica, 22 November 1969.

Ibid., art. 61. 
cases before the Court involving indigenous peoples and these are discussed in the next section.

The American Declaration represents a statement of individual rights and duties and, according to Patrick Thornberry, “does not carry a specific indigenous imprint.”137 However, the Inter-American Court of Human Rights takes the view that the Declaration represents an interpretation of the human rights provisions of the OAS Charter and, as such, is binding on individual states by virtue of their membership in the OAS. This is significant since a number of OAS states (including Canada, the U.S., and Belize) are not parties to the American Convention. The Inter-American Commission on Human Rights echoes this understanding of the normative effect of the Declaration in cases involving each of these three states: ${ }^{138}$ "the American Declaration constitutes a source of international legal obligation for all member states of the Organization of American States, including Canada." ${ }^{339}$ Furthermore, the Commission takes the view that, in interpreting the Declaration, it should take account of the "American Convention on Human Rights which, in many instances, may be considered to represent an authoritative expression of the fundamental principles set forth in the American Declaration.”140

The American Convention is comprised of three parts. Part I establishes the protected rights and the correlative obligations of the state. Part II is largely concerned with establishing the responsibilities of the Commission and the Court.

While neither of these instruments deals explicitly with the rights of indigenous peoples or even the rights of minorities, the Court (in the case of the Convention) and the Commission (in the case of the Declaration) have both been prepared to interpret the basic rights of these two instruments in a manner that is sensitive to the special circumstances of indigenous peoples. This approach to interpretation also limits the power of the state to deal with natural resources within the traditional territories of indigenous peoples without first recognizing, delimiting, and demarcating the land and resource interests of indigenous peoples. The following sections deal successively with the jurisprudence of the Court and then the Commission.

\section{A. THE JURISPRUDENCE OF THE INTER-AMERICAN COURT OF HUMAN RightS}

The jurisprudence of the Court in relation to indigenous peoples and resource development has focused on two main provisions of the American Convention: the art. 21 protection of property and the art. 25 right to judicial protection. The Court has also referred to the

Thornberry, supra note 29 at 268.

Maya Indigenous Communities of the Toledo District v. Belize (2004), Inter-Am. Comm. H.R. No. 40/04, Annual Report of the Inter-American Commission on Human Rights: 2004, OEA/Ser.L/ V/II.122/doc.5, rev.1 (2005) 727 [Maya Communities]; Mary \& Carrie Dann v. United States (2002), Inter-Am. Comm. H.R. No. 75/02, Annual Report of the Inter-American Commission on Human Rights: 2002, OEA/Ser.L/V/II.117/doc.5 rev.1 (2003) 860 [Dann]; Grand Chief Michael Mitchell v. Canada (2003), Inter-Am. Comm. H.R. No. 74/03, Annual Report of the Inter-American Commission on Human Rights: 2003, OEA/Ser.L/V/II.118/doc.70 rev.2 (2003) 160 [Grand Chief Mitchell, Admissibility]. Grand Chief Michael Mitchell v. Canada (2008), Inter-Am. Comm. H.R. No. 61/08 at para. 62, Annual Report of the Inter-American Commission on Human Rights: 2008, OEA/Ser.L/V/II.134/doc.5 rev.1 (2009) 160 [Grand Chief Mitchell, Merits].

Ibid. at para. 64. 
preliminary provisions of the Convention dealing with the obligation to respect rights without discrimination (art. 1) and the duty to give legal effect to protected rights (art. 2). ${ }^{141}$ I begin with the case law on the right to judicial protection before turning to the right to property.

\section{B. The Right to Judicial Protection}

Article 25 of the American Convention provides that:

1. Everyone has the right to simple and prompt recourse, or any other effective recourse, to a competent court or tribunal for protection against acts that violate his fundamental rights recognized by the constitution or laws of the state concerned or by this Convention, even though such violation may have been committed by persons acting in the course of their official duties.

2. The States Parties undertake:

a. To ensure that any person claiming such remedy shall have his rights determined by the competent authority provided for by the legal system of the state;

b. To develop the possibilities of judicial remedy; and

c. To ensure that the competent authorities shall enforce such remedies when granted. ${ }^{142}$

There are two aspects of this provision that deserve comment. The provision recognizes the importance of ensuring that the rights holder has an effective remedy. What counts as an effective remedy will vary to some extent with the right that is at issue. In some cases the focus may be on an appropriate judicial remedy, including the possibility of injunctive-style relief or judicial review. But in other cases the remedy may need to reach beyond this in order to create a more appropriate and effective protective regime, as illustrated below in the decisions that emphasize the obligation of the state to recognize, delimit, and demarcate indigenous property interests. A second important aspect of art. 25 is the breadth of the interests and rights that it protects. The article does not just demand an effective remedy for rights protected by the Convention itself, it also protects "fundamental rights recognized by the constitution or laws of the state concerned." This function too is evident in the decisions below (starting with the Awas Tingni ${ }^{143}$ decision), which demonstrate, at least within the Inter-American system, that constitutional rights statements are more than empty rhetoric and that this Court will endeavour to give them real meaning.

The Awas Tingni community claimed traditional territory within Nicaragua. The state had never confirmed community title to the lands, and, in 1996, an arm of the state entered into a forest concession agreement with a foreign company. Alleging a breach of art. 25, the

The Court has also suggested that the continued separation of tribal members from ancestral territories may constitute a breach of the American Convention, supra note 23, art. 5(1) ("Every person has the right to have his physical, mental, and moral integrity respected") insofar as connection with a particular territory is of "vital spiritual, cultural and material importance": see Case of the Moiwana Community v. Suriname (2005), Inter-Am. Ct. H.R. (Ser.C) No. 124 at para. 101 [Moiwana Community]; the same facts might give rise to a breach of art. 22 (freedom of movement): ibid. at para. 120 . 
community drew attention to the fact that the 1995 amendments to the Constitution of Nicaragua ${ }^{144}$ protected indigenous land and other rights, as did various domestic laws on the demarcation of indigenous lands. However, there was considerable uncertainty as to how these rules should be applied and the Court noted that no title deeds had in fact been issued to indigenous communities since 1990. In light of this, the Court concluded that there is "no effective procedure in Nicaragua for delimitation, demarcation, and titling of indigenous communal lands.” ${ }^{145}$ This was held to be a breach of art. 25 and also a breach of arts. 1(1) and 2 of the American Convention.

Article 25 was also at issue in two cases involving Paraguay: the Yakye Axa ${ }^{146}$ and Sawhoyamaxa. ${ }^{147}$ The facts of each were similar; the focus here is on the facts of the Yakye Axa case. The Yakye Axa community was dispossessed of its land through the process of colonization. Title to these lands became vested in various corporations. The Yakye Axa people were eventually resettled on other lands through the work of a religious order but these arrangements were never satisfactory. Accordingly, in 1993, the community resolved to try to resettle on their traditional lands, relying on a provision of the Paraguayan Constitution $^{148}$ as well as a domestic law that provided for the compulsory acquisition of lands in order to provide for an indigenous community. Various efforts over a long period of time failed to progress this agenda and the community eventually brought a case to the Commission, which then proceeded to the Court, alleging a breach, inter alia, of art. 25. The Court found that Paraguay was in breach of art. 25 in association with arts. 1(1) and 2 of the American Convention by failing to put in place an effective and simple procedure to process the land claims of indigenous people in such a way that they "have a real opportunity to recover their lands.”149

In sum, these cases impose a high standard of effective protection. The substantive standard that the state must reach may be drawn from the Convention, the constitution of the state, or the domestic law of the state. The cases reach beyond purely judicial remedies strictly conceived and require that the overall machinery of the state be brought to bear to ensure that the substantive promise of the Convention, the constitution, and domestic laws can all be achieved.

See Amendments to the Constitution (1995) 124 La Gaceta, Diario Oficial, online: Global Lega Information Network (GLIN) <http://www.glin.gov/view.action?glinID=136602>, as cited in ibid. at paras. 116-18. by virtue of failing to provide effective judicial remedies (amparo) to protect the indigenous interest. Case of the Yakye Axa Indigenous Community v. Paraguay (2005), Inter-Am. Ct. H.R. (Ser.C) No. 125 [Yakye Axa]. Case of the Sawhoyamaxa Indigenous Community v. Paraguay (2006), Inter-Am. Ct. H.R. (Ser.C) No. 146 [Sawhoyamaxa].

148 Constitución Nacional de la República del Paraguay (1992) 63 Gaceta Oficial de la Republica del Paraguay, online: GLIN <http://www.glin.gov/view.action?glinID=76156>, as cited in Yakye Axa, supra note 146 at para. 74 .

149 Yakye Axa, ibid. at para. 102. For a similar discussion see Sawhoyamaxa, supra note 147 at paras. 93112. 


\section{The Right to Property}

Many (but not all) international human rights instruments protect the right to property. For example, art. 17 of the Universal Declaration of Human Rights provides that:

(1) Everyone has the right to own property alone as well as in association with others.

(2) No one shall be arbitrarily deprived of his property. ${ }^{150}$

Similarly, the European Convention for the Protection of Human Rights and Fundamental Freedoms ${ }^{151}$ (first adopted in 1950) was soon amended by its first protocol (adopted in 1952) to provide that

[e]very natural or legal person is entitled to the peaceful enjoyment of his possessions. No one shall be deprived of his possessions except in the public interest and subject to the conditions provided for by law and by the general principles of international law.

The preceding provisions shall not, however, in any way impair the right of a State to enforce such laws as it deems necessary to control the use of property in accordance with the general interest or to secure the payment of taxes or other contributions or penalties. ${ }^{152}$

The two international covenants (the ICCPR and the ICESCR) do not protect property rights but that omission is an artifact of the ideological differences between East and West. The American Convention, like the European Convention, does protect property rights. Article 21 of the American Convention provides that:

1. Everyone has the right to the use and enjoyment of his property. The law may subordinate such use and enjoyment to the interest of society.

2. No one shall be deprived of his property except upon payment of just compensation, for reasons of public utility or social interest, and in the cases and according to the forms established by law.

3. Usury and any other form of exploitation of man by man shall be prohibited by law. ${ }^{153}$

GA Res. 217 (III), UN GAOR, 3d Sess., Supp. No. 13, UN Doc. A/810 (1948) 71, art. 17. See Alexandra Xanthaki, Indigenous Rights and United Nations Standards: Self-Determination, Culture and Land (Cambridge: Cambridge University Press, 2007). After noting the silence of the two Covenants on property rights, Xanthaki remarks that "[o]ther universal instruments only protect the individual right to property; consequently they are not helpful to indigenous claims" (at 243). It is not entirely clear which other universal instruments Xanthaki is referring to, but as will become apparent this pessimistic assessment certainly does not apply to the Inter-American instruments.

4 November 1950, 213 U.N.T.S. 221 [European Convention].

Ibid., art. 1.
American Convention, supra note 23, art. 21. There is a significant body of case law on this provision, some of it dealing with the nexus between the right to property and environmental degradation (see e.g. Hatton v. The United Kingdom (2003), 37 E.H.H.R. 28, although generally litigants and the Court prefer to rely on the art. 8 right to respect for privacy, family life, and home) and some of it dealing with loss of land (extinguishment) due to the operation of limitations legislation (see e.g. and most recently J.A. Pye (Oxford) Ltd. v. United Kingdom (2008), 46 E.H.R.R. 45). The Court emphasizes that art. 1 contains three distinct (but connected) rules: (1) the principle of peaceful enjoyment of property; (2) the deprivation of possession is subject to certain conditions; and (3) the state may control the use of property in the public interest but subject to review on proportionality/fair balance rules. 
The Court first considered the application of art. 21 in the context of indigenous people in Awas Tingni. As a result, the Court had to consider the threshold question of whether art. 21 could protect communal indigenous titles as well as state-granted individual property rights. The Court, relying to some degree on an evolutive interpretation of international treaties and, especially, human rights treaties, ${ }^{154}$ held affirmatively and that the quality of the protected right might be determined in part by reference to the customary laws of the indigenous peoples:

\begin{abstract}
Among indigenous peoples there is a communitarian tradition regarding a communal form of collective property of the land, in the sense that ownership of the land is not centered on an individual but rather on the group and its community. Indigenous groups, by the fact of their very existence, have the right to live freely in their own territory; the close ties of indigenous people with the land must be recognized and understood as the fundamental basis of their cultures, their spiritual life, their integrity, and their economic survival. For indigenous communities, relations to the land are not merely a matter of possession and production but a material and spiritual element which they must fully enjoy, even to preserve their cultural legacy and transmit it to future generations.
\end{abstract}

Indigenous peoples' customary law must be especially taken into account for the purpose of this analysis. As a result of customary practices, possession of the land should suffice for indigenous communities lacking real title to property of the land to obtain official recognition of that property, and for consequent registration. $^{155}$

The property rights of the Awas Tingni were protected by art. 21, but to what extent? And how did those protected rights relate to those of other indigenous communities? And if the rights were protected, could the state grant timber harvesting rights to a third party? The Court's response to these questions was as follows:

[T] he Court notes that the limits of the territory on which that property right exists have not been effectively delimited and demarcated by the State. This situation has created a climate of constant uncertainty among the members of the Awas Tingni Community, insofar as they do not know for certain how far their communal property extends geographically and, therefore, they do not know until where they can freely use and enjoy their respective property. Based on this understanding, the Court considers that the members of the Awas Tingni Community have the right that the State

a) carry out the delimitation, demarcation, and titling of the territory belonging to the Community; and

b) abstain from carrying out, until that delimitation, demarcation, and titling have been done, actions that might lead the agents of the State itself, or third parties acting with its acquiescence or its tolerance, to affect the existence, value, use or enjoyment of the property located in the geographical area where the members of the Community live and carry out their activities. 
Based on the above ... the Court believes that, in light of article 21 of the Convention, the State has violated the right of the members of the Mayagna Awas Tingni Community to the use and enjoyment of their property, and that it has granted concessions to third parties to utilize the property and resources located in an area which could correspond, fully or in part, to the lands which must be delimited, demarcated, and titled. $^{156}$

Since then, the Court has consistently emphasized the importance of the state's duty to delimit, demarcate, and title indigenous and tribal lands, and to refrain from actions that "would affect the existence, value, use or enjoyment" of lands within such a claimed area until the right to property is secured. ${ }^{157}$

The right to property was also at issue in the Yakye Axa decision, although from the facts noted above it is clear that the case was more complicated than Awas Tingni. In Yakye Axa, the Court had to deal with competing property claims: the property claims of the current titled "owners" and the claims of the indigenous community for the return of the land. The case is not completely on point for present purposes (since it does not deal with state authorized resource development in traditional territory), but it is nevertheless important for several reasons. ${ }^{158}$

First, the Court's decision again serves to emphasize the importance and significance of land to indigenous communities. ${ }^{159}$ Second, where there are competing claims to land by indigenous communities and private owners, the state must be careful to resolve those disputes in a manner that fulfills an imperative public interest (in this case, restoration of indigenous property interests). At the same time, any interference with a protected right, such as the rights of the current titled owners, must be proportional to the goal sought to be achieved. Restrictions on protected rights can only be justified through the importance of the goal to be achieved. As the Court noted in this case:

\footnotetext{
When they apply these standards to clashes between private property and claims for ancestral property by the members of indigenous communities, the States must assess, on a case by case basis, the restrictions that would result from recognizing one right over the other. Thus, for example, the States must take into account that indigenous territorial rights encompass a broader and different concept that relates to the collective right to survival as an organized people, with control over their habitat as a necessary condition for reproduction of their culture, for their own development and to carry out their life aspirations. Property of the land ensures that the members of the indigenous communities preserve their cultural heritage. ${ }^{160}$
}

Ibid. at para. 153.

See e.g. Moiwana Community, supra note 141 at paras. 209-11.

Paraguay is a party to the $I L O$ Convention 169 and accordingly the judgment draws upon the content of that Convention to help inform the Court's interpretation of the right to property and in particular the interests associated with indigenous claims to property.

Yakye Axa, supra note 146 at para. 135:

The culture of the members of the indigenous communities directly relates to a specific way of being, seeing, and acting in the world, developed on the basis of their close relationship with their traditional territories and the resources therein, not only because they are their main means of subsistence, but also because they are part of their worldview, their religiosity, and therefore, of their cultural identity. Ibid. at para. 146. 
Thus, in at least some cases, a state taking of property to restore land and territory to an indigenous people might be proportionate if the current title holder were to be compensated. ${ }^{161}$ The Court does not take this to mean that the state would always be required to take from current owners to restore lands to the indigenous owners. However, if states were not able or not required to do so for "concrete and justified reasons," then compensation should be paid based on the value that the land would have to the indigenous owner. ${ }^{162}$

As noted above, the fact pattern of the Sawhoyamaxa case was similar to that of the Yakye Axa and the result along the same lines. However, in Sawhoyamaxa, the Court elaborated on its reasoning from that earlier decision. First, the Court emphasized that different conceptions of property, including community based and individual ideas of property, are deserving of equal protection under art. 21, holding that "[d]isregard for specific versions of use and enjoyment of property, springing from the culture, uses, customs, and beliefs of each people, would be tantamount to holding that there is only one way of using and disposing of property, which, in turn, would render protection under Article 21 of the Convention illusory for millions of persons." "163 Second, the Court gave its opinion on the question of whether continuing possession of lands by an indigenous community was a prerequisite for the official recognition of title. The Court rejected that contention and, in the course of doing so, adumbrated four principles that could be derived from the Court's case law:

1) traditional possession of their lands by indigenous people has equivalent effects to those of a state-granted full property title; 2) traditional possession entitles indigenous people to demand official recognition and registration of property title; 3 ) the members of indigenous peoples who have unwillingly left their traditional lands, or lost possession thereof, maintain property rights thereto, even though they lack legal title, unless the lands have been lawfully transferred to third parties in good faith; and 4) the members of indigenous peoples who have unwillingly lost possession of their lands, when those lands have been lawfully transferred to innocent third parties, are entitled to restitution thereof or to obtain other lands of equal extension and quality. Consequently, possession is not a requisite conditioning the existence of indigenous land restitution rights. The instant case is categorized under this last conclusion. ${ }^{164}$

Third, the Court examined whether a claim to restitution is time limited. On that point the Court held that a restitutionary claim might continue for so long as the indigenous community could claim some continuing relationship with land. That relationship "must be possible" rather than simply theoretical, but might still be maintained if indigenous communities are prevented from maintaining that relationship by reasons beyond their control, such as acts of violence. ${ }^{165}$

Fourth, the Court in Sawhoyamaxa offered additional guidance to the state in dealing with the competing claims of the indigenous community and the titled owner. The Court acknowledged that it lacked the authority to decide that the lands should be returned to the traditional owners, but it did suggest that it had the competence to assess whether the

162 Ibid. at para. 149 ("the compensation granted must be guided primarily by the meaning of the land for them").

163 Sawhoyamaxa, supra note 147 at para. 120. 
arguments offered by the state were sufficiently compelling to justify non-restitution in this case. Paraguay relied upon the long-standing title of the nominal owners, the claim that the owners were putting the lands to productive use, and the claim that the state's hands were tied in dealing with the titled owners because the latter were protected by the terms of a bilateral investment treaty (BIT) between Germany and Paraguay. The Court rejected all three arguments. The first argument could hardly be conclusive since it would mean that all claims to restitution would fail absent agreement between the current owner and the indigenous community. The second argument failed because it was insufficiently sensitive to the possibility of a special connection between the indigenous community and the land and overly solicitous of the interests and values of the titled owner:

This argument lodges the idea that indigenous communities are not entitled, under any circumstances, to claim traditional lands ... when they are exploited and fully productive, viewing the indigenous issue exclusively from the standpoint of land productivity and agrarian law, something which is insufficient for it fails to address the distinctive characteristics of such peoples. ${ }^{166}$

Finally the Court rejected the BIT argument on the grounds that the BIT permitted expropriation in the public interest (and presumably on payment of compensation), and that this "could justify land restitution to indigenous people."167 Furthermore, the Court was by no means convinced that there was a conflict since enforcement of such BITs should always be compatible with the terms of multilateral human rights instruments such as the American Convention. ${ }^{168}$

The Saramaka ${ }^{169}$ case is both the most recent decision of the Court dealing with indigenous (or in this case tribal) peoples and resource development and the most important. The Saramaka people (or Maroons, descendants of African slaves first brought to Suriname in the seventeenth century who escaped and established autonomous communities in the forested interior) alleged that the state was, inter alia, violating their protected property rights through a series of activities including mining operations and forestry and logging operations within areas traditionally used by the Saramaka. ${ }^{170}$ Unlike the earlier decisions in which the applicants and the Court relied in part on art. 25 of the Convention, in this case the property rights protection of art. 21 was front and centre. Part of the reason, if not the main reason, for this was that Saramakan law (unlike the domestic laws and constitutions of Nicaragua and Paraguay) did not protect the communal property interests of tribal communities. ${ }^{171}$

Ibid. at para. 139.

Ibid. at para. 140 .

Ibid.

Case of the Saramaka People v. Suriname (2007), Inter-Am. Ct. H.R. (Ser.C) No. 172 [Saramaka, Merits]; Case of the Saramaka People v. Suriname (2008), Inter-Am. Ct. H.R. (Ser.C) No. 185 [Saramaka, Interpretation]; for comment see Lisl Brunner, "The Rise of Peoples' Rights in the Americas: The Saramaka Peoples’ Decision of the Inter-American Court of Human Rights” (2008) 7 Chinese Journal of International Law 699 (emphasizing that the Court elected to link the Inter-American instruments with the recognition of the rights of peoples under the international Covenants).

The Saramaka also argued that the state had interfered with their territory through the construction and operation of the Abofaka dam and related reservoir but the Court held that it had no competence in relation to those matters since they were not included in the original complaint that had been brought before the Commission (Saramaka, Merits, ibid. at paras. 11-17). Ibid. at para 92. 
Thus, in Saramaka, the applicants and the Court could not rely on one important aspect of art. 25 (the protection of rights accorded under domestic law), and neither could they rely on art. 29(b) of the American Convention, which the Court has interpreted as prohibiting any interpretation that restricts the protection offered to less than that recognized in the domestic law of that state or another treaty to which that state is a party. ${ }^{172}$ The Court noted that Suriname, while not a party to the ILO Convention 169, was a party to both international Covenants, and the Court concluded, reading together common art. 1 and art. 27 of the $I C C P R$, that

\begin{abstract}
the members of the Saramaka people make up a tribal community protected by international human rights law that secures the right to the communal territory they have traditionally used and occupied, derived from their longstanding use and occupation of the land and resources necessary for their physical and cultural survival, and that the State has an obligation to adopt special measures to recognize, respect, protect and guarantee the communal property right of the members of the Saramaka community to said territory. ${ }^{173}$
\end{abstract}

In its defence, Suriname argued that the state did provide de facto protection to Saramaka property interests in a number of ways and that the Saramaka were eligible to apply for a greater degree of protection. The Court held that this was inadequate both because it fell short of the protection offered to other property rights holders ${ }^{174}$ and because a protected right could not depend upon the exercise of a discretionary power by a Minister. ${ }^{175}$

The Court examined the nature, quality, and content of the Saramakan property interest, noting that both the state and the Saramaka people claimed rights in relation to natural resources, including timber and minerals. ${ }^{176}$ The Court concluded that the Saramaka's protected interest should extend to those "natural resources found on and within indigenous and tribal people's territories that are ... traditionally used and necessary for the very survival, development and continuation of such people's way of life.”177 That conclusion in turn prompted the Court to inquire as to what those resources would be and the extent to which the state might grant third parties interests in "those and other natural resources found within Saramaka territory."

\title{
D. The Content of The Protected InTerest
}

As to the first line of inquiry, ${ }^{179}$ the Court found that evidence of extensive and intensive use of forest products fully supported the conclusion that "the members of the Saramaka people have traditionally harvested, used, traded and sold timber and non-timber forest

See e.g. Awas Tingni, supra note 20 at paras. 111, 147.

Saramaka, Merits, supra note 169 at para. 96.

Ibid. at para. 110.

Ibid. at para. 113. See the discussion in R. v. Adams, [1996] 3 S.C.R. 101 at 131-32 to the effect that an unstructured discretionary power to grant or withhold an entitlement to fish for food constituted an infringement of an aboriginal right.

Saramaka, Merits, ibid. at para. 119.

Ibid. at para. 122.

Ibid. at para. 123.

In fact, and somewhat strangely (see further discussion below), the Court started with the second question, the power of the state (ibid. at paras. 124-43), before determining the content of the protected right (ibid. at para. 144ff). I reverse the order here since, in my view, we first need to know whether the Saramaka people can claim a property interest in the lands before assessing the power of the state to dispose of those lands. 
products, and continue to do so until the present day."180 The evidence was different in relation to minerals, particularly gold. Here, the evidence suggested that

\begin{abstract}
the members of the Saramaka people have not traditionally used gold as part of their cultural identity or economic system. Despite possible individual exceptions, members of the Saramaka people do not identify themselves with gold nor have demonstrated a particular relationship with this natural resource, other than claiming a general right to "own everything, from the very top of the trees to the very deepest place that you could go under the ground." 181
\end{abstract}

However, the Court went on to recognize that while the Saramaka people could not maintain the same claim in relation to minerals that they could in relation to the forestry resource, the state would still need to take account of the interests of the Saramaka people in granting third party rights, insofar as the activities of those parties might have an effect on other activities of the Saramaka.

\title{
E. The Power of The Saramaka State
}

Having ascertained the content of the property interest of the Saramaka, the Court then turned to the position of the state with respect to those resources. Here, the Court emphasized that the rights protected by art. 21 are not absolute and that art. 21 itself contemplated some limits on the level of protection it afforded. Drawing upon cases involving both indigenous and non-indigenous peoples, the Court indicated that "a State may restrict the use and enjoyment of the right to property where the restrictions are: a) previously established by law; b) necessary; c) proportional, and d) with the aim of achieving a legitimate objective in a democratic society." "182 However, in the case of indigenous peoples, the Court took the view that the state must meet an additional test, to the effect that "the State may restrict the Saramakas' right to use and enjoy their traditionally owned lands and natural resources only when such restriction complies with the aforementioned requirements and, additionally, when it does not deny their survival as a tribal people.”183

In order to give effect to that last condition, the Court developed what it referred to as "three safeguards" that the state would need to comply with in order "to guarantee that restrictions to the property rights of the members of the Saramaka people by the issuance of concessions within their territory does not amount to a denial of their survival as a tribal people."184

First, the state should ensure the effective participation of the Saramaka people in decision-making in relation to any “development or investment plan” 185 within their territory. This should involve informed and good faith consultation "with the objective of reaching an agreement," but in the case of a "large-scale development or investment projects that would

\footnotetext{
$180 \quad$ Ibid. at para. 146.

$181 \quad$ Ibid. at para. 155.

$182 \quad$ Ibid. at para. 127.

$183 \quad$ Ibid. at para. 128.

184 Ibid at para. 129. The Court elaborated on these safeguards in response to the state's request for an interpretation of its judgment: see Saramaka, Interpretation, supra note 169.

185 The Court uses this term in Saramaka, Merits, supra note 169 at para. 129 to refer compendiously to "any development, investment, exploration or extraction plan."
} 
have a major impact within Saramaka territory, the State has a duty, not only to consult with the Saramakas, but also to obtain their free, prior, and informed consent, according to their customs and traditions.”186

Second, in considering development or investment plans, the state must engage in benefit sharing consistent with the just compensation clause of art. 21. Benefit sharing should "be understood as a form of reasonable equitable compensation resulting from the exploitation of traditionally owned lands and of those natural resources necessary for the survival of the Saramaka people." 187

Third, "the State must ensure that no concession will be issued within Saramaka territory unless and until independent and technically capable entities, with the State's supervision, perform a prior environmental and social impact assessment." ${ }^{188}$ In its judgment, the Court emphasized that any such assessment "must conform to the relevant international standards and best practices" and must take account of the cumulative impact of existing and future activities. $^{189}$

Applying these safeguards to the situation of timber concessions, the Court concluded as follows:

[T] he logging concessions issued by the State in the Upper Suriname River lands have damaged the environment and the deterioration has had a negative impact on lands and natural resources traditionally used by members of the Saramaka people that are, in whole or in part, within the limits of the territory to which they have a communal property right. The State failed to carry out or supervise environmental and social impact assessments and failed to put in place adequate safeguards and mechanisms in order to ensure that these logging concessions would not cause major damage to Saramaka territory and communities. Furthermore, the State did not allow for the effective participation of the Saramakas in the decision-making process regarding these logging concessions, in conformity with their traditions and customs, nor did the members of the Saramaka people receive any benefit from the logging in their territory. All of the above constitutes a violation of the property rights of the members of the Saramaka people recognized under Article 21 of the Convention, in connection with Article 1.1 of said instrument. ${ }^{190}$

The Court reached a similar conclusion in relation to the mining concession even though, as noted above, the Court concluded that the Saramaka had not traditionally used gold. Because of the risk of harm that mining might pose to traditional activities, the Court was of the view that all three safeguards should apply and that "[t]he same analysis applies regarding other

Ibid. at paras. 133-34; see also para. 137 where the test is stated as a development that "may have a profound impact on the property rights of the members of the Saramaka people to a large part of their territory.” In Saramaka, Interpretation, supra note 169, the Court emphasized that it was the Saramaka who must determine which tribal members are to be involved in the consultations (at paras. 15, 18). In that same judgment the Court went on to list six matters for consultation (at para. 16). Saramaka, Merits, ibid. at para. 140. In its Saramaka, Interpretation, judgment the Court noted that the term "survival" meant "much more than physical survival" and referred to their distinctive cultural identity, social structure, beliefs, traditions, etc. (at para. 37). Saramaka, Merits, ibid. at para. 129

Saramaka, Interpretation, supra note 169 at para. 41 [footnote omitted]. The footnote referred to the Akwe Kon Guidelines, which set out standards that can be used in conducting environmental and social impact assessments in the context of indigenous peoples and can be found online: Secretariat of the Convention on Biological Diversity <http://www.cbd.int/doc/publications/akwe-brochure-en.pdf>. Saramaka, Merits, supra note 169 at para. 154. 
concessions within Saramaka territory involving natural resources which have not been traditionally used by members of the Saramaka community, but that their extraction will necessarily affect other resources that are vital to their way of life.”191

Finally, and since the concession in this case had already been granted, the Court considered the state's position in relation to those existing third party rights. Here, the Court recalled its earlier jurisprudence, particularly the Yakye Axe and Sawhoyamaxa decisions, and concluded that "the State has a duty to evaluate ... whether a restriction of these private property rights is necessary to preserve the survival of the Saramaka people."192

Since the Court had found that the state had violated the protected rights of the Saramaka people, it turned to the matter of remedy. While much of this section of the judgment tracks the earlier substantive discussion, several points deserve attention. First, the Court emphasized (consistently with its earlier decisions) that the state needed to provide effective protection for Saramakan property rights. To that end, the state must engage in a process of delimitation, demarcation, and granting of Saramaka titles. ${ }^{193}$ Second, the state must provide effective legislative and administrative procedures for the protection of those rights and must put in place the necessary measures to provide for the three safeguards.

It is evident that the Saramaka judgment is far-reaching. It builds on and confirms the Court's earlier decisions but also adds to those decisions in significant ways. In particular, it confirms that indigenous property interests may include a significant resource dimension. The decision also develops an impressive body of safeguards (effective participation and, in some cases, consent; benefit sharing; and environmental and social impact assessments) that must be in place before resource development occurs in traditional territories. But the case is not free from difficulty. First, while the decision recognizes a resource dimension, it does so only to the extent that such resources are traditionally used and essential to survival. While the first part (the traditional use) of this test is perhaps unexceptional, ${ }^{194}$ the idea that proving something to be essential to survival as part of establishing a property claim seems much more contentious. Such a characterization may be relevant in a case such as Yakye Axa in deciding which of two competing property interests a state should prefer, but it hardly seems relevant to determine whether or not an indigenous people can maintain a property claim in the first instance. Second, the Court seems to be unwilling to recognize the full implications of finding a protected property interest. I say this because the Court seems to be of the view that the state can still dispose of resource interests (subject to safeguards) even if those resources are found to be owned by the Saramakans. While I understand that the American Convention recognizes that property is a social institution and that the state may take the property of a subject for legitimate public purposes, the idea that the state can, in the

aid. at para. 155

Ibid. at para. 157.

Ibid. at para. 194; see also para. 173 where the Court explains that Saramaka people remain vulnerable for so long as Saramaka property interests may be trumped by individual property rights. And in Saramaka, Interpretation, supra note 169, the Court added that the State must "adopt special measures that guarantee the members of the Saramaka people the full and equal exercise of their right to the territories they have traditionally used and occupied” (at para. 33).

For different approaches to assessing the content of the resource dimensions of an indigenous title see Nigel Bankes, "Aboriginal Title to Petroleum: Some Comparative Observations on the Law of Canada, Australia, and the United States” (2004) 7 Yearbook of New Zealand Jurisprudence 111. 
ordinary course, deal with Saramakan resource interests as though those belong to the state is wrong.

\section{F. CONCLUSIONS WITH RESPECT TO THE JURISPRUDENCE OF THE COURT}

In fewer than ten years, the Inter-American Court has transformed the international legal status of the land and resource rights of indigenous people, and it has done this in large part by taking seriously the property rights of indigenous peoples. The Court has insisted that the property rights of indigenous peoples that survived settlement and colonization are equally deserving of recognition and protection as are the state-granted rights of settlers. Furthermore, the Court has articulated a threefold duty to delimit, demarcate, and title indigenous lands. To further protect indigenous interests, the Court has also concluded that the state should not engage in granting resource dispositions to others within claimed traditional territories unless and until the state has delivered on the required titling process. ${ }^{195}$ In sum, settlements with indigenous peoples must be based on an appreciation of a legal entitlement rather than just political expediency.

\section{G. THE JURISPRUDENCE OF THE COMMISSION ON THE AMERICAN DECLARATION ON THE RIGHTS AND DUTIES OF MAN}

As noted above, the Commission has commented on the relationship between indigenous peoples and resource development as part of its country reports, but it has also had occasion to comment on these issues in response to petitions. The Commission's most significant report relating to resource developments in traditional territory is its report in response to a petition presented to the Commission by the Maya Indigenous Communities of the Toledo District against the state of Belize, which, like the United States and Canada, is not a party to the American Convention. ${ }^{196}$

The Maya Indigenous Communities argued that Belize was in breach of its obligations under, inter alia, art. XXIII (the right to property) and art. II (equality before the law) by granting numerous logging concessions and at least one oil concession on lands used and occupied by the Maya people. The Commission's decision was published in 2004, after the Court's decision in the Awas Tingni case but before the Court's subsequent decisions involving Paraguay. The Commission's report builds on the Court's decision in Awas Tingni in relation to the property rights claim, but also develops a new line of analysis based on the

195 There is some reason, however, for questioning the subsequent implementation of the Court's decisions. For example, in Human Rights Committee, Consideration of Reports Submitted by States Parties Under Article 40 of the Covenant, Concluding Observations of the Human Rights Committee, Nicaragua, UN HRCOR, 94th Sess., UN Doc. CCPR/C/NIC/CO/3 (2008) [Concluding Observations re: Nicaragua] the Human Rights Committee (referring to arts. 26-27 of the ICCPR) noted that "more than six years after the ruling handed down by the Inter-American Court in the Awas Tingni case, the community still has no title of ownership, while the Awas Tingni region continues to be prey to illegal activity by outside settlers and loggers" (at para. 21). The Committee went on the recommend that the state should:

Conduct consultations with indigenous peoples before granting licences for the economic exploitation of the lands where they live, and ensure that such exploitation in no circumstances infringes the rights acknowledged in the Covenant [and] [c]ontinue and complete the process of delimiting, demarcating and granting title to the lands of the Awas Tingni community, prevent and check illegal activity by outsiders on those lands, and investigate and punish those responsible for such activity (ibid.). 
idea of equality before the law. This is potentially very significant since all human rights instruments recognize this value even if they do not recognize property rights. ${ }^{197}$

\section{H. THE Right TO PROPERTy}

Article XXIII of the American Declaration provides that: "Every person has a right to own such private property as meets the essential needs of decent living and helps to maintain the dignity of the individual and of the home." 198 The Commission acknowledged that some Maya lands were protected as reserves in a system that seems to resemble the system of Indian reserves in Canada, but took the view that this was inadequate for a number of reasons. Traditional territories extended beyond reserve boundaries and even the boundaries of those reserves were never clearly defined, surveyed, or demarcated on the ground. ${ }^{199}$ This, the Commission found, was a breach of the right to property. The state had a duty to recognize and protect the indigenous property interest but had "failed to delimit, demarcate and title or otherwise establish the legal mechanisms necessary to clarify and protect the territory on which their right exists." 200 As such, Belize was in breach of art. XXIII. But what of the concessions that Belize had already granted? These too amounted to a breach because of the state's failure to engage in "effective and fully informed consultations"201 and because it was granting rights "to third parties to utilize property and resources that could fall within the traditional lands of the Maya people.” ${ }^{\text {202 }}$ Furthermore, this breach was exacerbated by the environmental damage that ensued from these resource concessions. ${ }^{203}$

\section{THE RIGHT TO EQUALITY BEFORE THE LAW}

Article II of the American Declaration provides that: “All persons are equal before the law and have the rights and duties established in this Declaration, without distinction as to race, sex, language, creed or any other factor."204 The right to equality before the law or to the equal protection of the law, or the obverse right not to be discriminated against, has played a significant role in human rights law and in the domestic jurisprudence of some states in relation to the legal protection of indigenous peoples (especially in Australia ${ }^{205}$ ) but it has not yet played a significant role in the jurisprudence of the Inter-American Court of Human Rights. The Court has not been completely silent on the topic, and in previous sections I have tried to highlight several instances in which the Court (especially in the context of the right to property) has contrasted the protections afforded to state-granted settler land titles with the absence of effective protection afforded to indigenous property interests. However, these arguments appear as an aside in the Court's decisions and the Court has yet to focus on the full implications of the right to equal protection of the law. Until that happens, the most

See e.g. the ICCPR, supra note 13, art. 26. The Human Rights Committee has referred to art. 26 as an ancillary support for its conclusions in cases principally founded on art. 27 in both petitions (see e.g. Lovelace, supra note 59) and in its concluding observations (see e.g. Concluding Observations re: Nicaragua, supra note 195).

American Declaration, supra note 24, art. XXIII.

Maya Communities, supra note 138 at paras. 106-109.

Ibid. at para. 135.

Ibid. at para. 142.

Ibid. at para. 144.

Ibid. at para. 148.

American Declaration, supra note 24, art. II.

See specifically Mabo \# 1, supra note 7. See also Sarah Pritchard, "Native Title from the Perspective of International Standards” (1997) 18 Australian Yearbook of International Law 127. 
sophisticated treatment of the issue is the Commission's report in this matter. In this case, the Commission concluded that Belize was in breach of its obligations under art. II with respect to both the clarification of indigenous property rights and the subsequent protection of those rights. Consonant with ideas of substantive equality in Canadian domestic law, ${ }^{206}$ the Commission was at pains to emphasize that the right to equality before the law does not require the identical treatment of indigenous property rights and state-granted property rights of settlers. Rather, the goal is true equality, and this may require the state to take special measures to eliminate conditions that cause or perpetuate discrimination, including vulnerabilities and threats. The Commission observed:

[T]he Commission has concluded that the Maya communities of southern Belize, as an indigenous people, constitute a distinct group in the Toledo District which warrants special protection from the State. It has also concluded that, in contrast to the treatment of property rights arising under the formal system of titling, leasing and permitting provided for under the law of Belize, the State has not established the legal mechanisms necessary to clarify and protect the communal property right of the Maya people. Indeed, the State has recognized that the Maya people have right to the lands and resources on southern Belize based on their longstanding use and occupancy and has acknowledged the need for state policies to protect the identity, dignity and social and cultural values of Belize's indigenous people, but has failed to take the steps necessary to recognize and guarantee those rights, resulting in a climate of uncertainty among the members of the Maya communities. ${ }^{207}$

In the domestic litigation that followed the Commission's report, the Court recognized the Maya indigenous title and supported that conclusion by referring to the duty not to discriminate, although it should be noted that in this case the Court chose to associate that duty with Belize's obligations under the CERD. ${ }^{208}$

More recently, the Commission has been asked to consider the relevance of the right to culture as protected in art. XIII of the American Declaration, which provides that:

Every person has the right to take part in the cultural life of the community, to enjoy the arts, and to participate in the benefits that result from intellectual progress, especially scientific discoveries.

He likewise has the right to the protection of his moral and material interests as regards his inventions or any literary, scientific or artistic works of which he is the author. ${ }^{209}$

Given the jurisprudence on art. 27 of the ICCPR, it is not unreasonable to explore the possible application of this articulation of the "right to culture.” However, the right to culture provision of the American Declaration is framed very differently from art. 27 and seems more concerned with intellectual property rights than indigenous land rights. In light of that and in light of the more obvious relevance of the property rights protection, it is hardly

Andrews v. Law Society of British Columbia, [1989] 1 S.C.R. 143 at 182 and recently reaffirmed in Ermineskin Indian Band and Nation v. Canada, 2009 SCC 9, [2009] 1 S.C.R. 222 at para. 188. Maya Communities, supra note 138 at para. 170. The analysis operates much like the equality provision of the Canadian Charter of Rights and Freedoms, s. 15, Part I of the Constitution Act, 1982, supra note 1, which can be used to extend the rights offered by provincial bills of rights: Vriend $v$. Alberta, [1998] 1 S.C.R. 493.

Aurelio Cal, supra note 25 at para. 123.

American Declaration, supra note 24, art. XIII. 
surprising that, to date, the only decision of the Commission that seems to have used the provision in the context of indigenous peoples is the Grand Chief Mitchell case. ${ }^{210}$

This case ${ }^{211}$ involved a claim that the imposition of customs duties on inter-cultural trade between Mohawk communities in the U.S. and Canada constituted a breach of the article. The Commission, while emphasizing in its admissibility decision that the right to culture had an autonomous meaning in international law and could not be controlled by domestic laws, ${ }^{212}$ ultimately rejected the petition. ${ }^{213}$ The Commission concluded that art. XIII does "protect those aspects of trade that can be said to be culturally significant in that they reflect ... a significant product or a culturally significant trading practice." ${ }^{\text {"14 }}$ However, the Commission found that the protection afforded by art. XIII was not absolute. In particular, the petitioners had failed to establish that Canada's imposition of customs tariffs prevented trade from occurring or had a disproportionate or discriminatory impact on a particular group. Absent evidence to this effect, the state had a right to exercise control over its borders through such measures and the Commission decided that "taxes, tariffs, and restrictions imposed on imported goods ... are reasonable limits that cannot be held to infringe cultural rights when they apply to all persons, regardless of their ethnicity or culture, and where it has not been demonstrated that such measures have a disproportionate or discriminatory impact on a particular group.”215

In conclusion, over the years the Commission has played a leadership role in bringing indigenous issues to the fore. It has done this through its country reports, by its responses to individual petitions, and by bringing cases forward to the Court, at least with respect to OAS members that are also party to the American Convention. For those states (such as Belize, the U.S., and Canada) that are not party to the Convention, the Commission represents the end of the road for an individual petitioner. Hence, for these states, the Commission's commentary is particularly significant. While the Commission's observations in relation to petitions from these states are necessarily based upon the language of the American Declaration rather the language of the Convention, the Commission has, at least in those cases dealing with property rights, ${ }^{216}$ been able to strengthen the authority and legitimacy of its comments by drawing upon relevant decisions of the Court, most notably to this time, the Awas Tingni decision.

\section{CONCLUSIONS}

International human rights law provides a set of standards against which to measure state behaviour. This body of law also serves as a limitation on state sovereignty insofar as it tells us that the state's treatment of its citizens, including minorities, is not simply a matter of domestic law but also a matter of international law and is therefore a legitimate international

Grand Chief Mitchell, Merits, supra note 139.

The case is the sequel to Mitchell v. M.N.R., 2001 SCC 33, [2001] 1 S.C.R. 911.

Grand Chief Mitchell, Admissibility, supra note 138 at para. 37. On autonomous meaning, see George Letsas, "The Truth in Autonomous Concepts: How to Interpret the ECHR” (2004) 15 E.J.I.L. 279. Grand Chief Mitchell, Merits, supra note 139.

Ibid. at para. 79. The Commission did refer to and draw upon the jurisprudence of the Human Rights Committee on art. 27 of the ICCPR and especially the three Länsman decisions.

Ibid. at para. 82.

Maya Communities, supra note 138; Dann, supra note 138. 
concern. My aim in this article has been to show that these propositions, which are well understood and accepted in relation to many areas of human rights law, also apply to the rights of indigenous peoples and especially in relation to the land and resource rights of indigenous peoples. I have tried to demonstrate this by reference to the decided "cases," in particular the cases and decisions arising in the context of both the ICCPR and the InterAmerican human rights instruments. For the most part I have not gone the extra step and tried to apply this jurisprudence to concrete fact patterns of resource development in traditional territories in Canada or elsewhere. That job, I think, is best left to be developed in particular cases before the courts and other tribunals, such as Alberta's Energy Resources Conservation Board. However, the conclusions to the discussion of art. 27 of the ICCPR do suggest how the art. 27 jurisprudence might be used to support arguments in domestic law that implicit within the "lands taken up" clause of the prairie treaties is a substantive limit (however framed) on the Crown's power to take up lands for the listed purposes. 